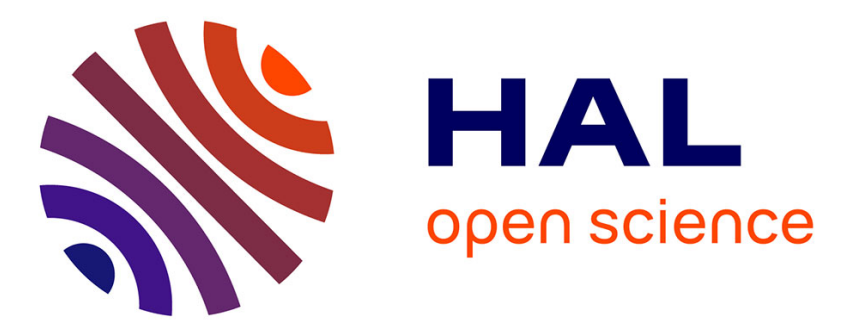

\title{
Parameter sensitivity to climate and landscape variability of a simple, lumped salt and water balance model
}

\author{
M. A. Bari, K. R. J. Smettem
}

\section{- To cite this version:}

M. A. Bari, K. R. J. Smettem. Parameter sensitivity to climate and landscape variability of a simple, lumped salt and water balance model. Hydrology and Earth System Sciences Discussions, 2005, 2 (4), pp.1405-1447. hal-00298690

\section{HAL Id: hal-00298690 \\ https://hal.science/hal-00298690}

Submitted on 9 Aug 2005

HAL is a multi-disciplinary open access archive for the deposit and dissemination of scientific research documents, whether they are published or not. The documents may come from teaching and research institutions in France or abroad, or from public or private research centers.
L'archive ouverte pluridisciplinaire HAL, est destinée au dépôt et à la diffusion de documents scientifiques de niveau recherche, publiés ou non, émanant des établissements d'enseignement et de recherche français ou étrangers, des laboratoires publics ou privés. 
Hydrol. Earth Sys. Sci. Discuss., 2, 1405-1447, 2005

www.copernicus.org/EGU/hess/hessd/2/1405/

SRef-ID: 1812-2116/hessd/2005-2-1405

European Geosciences Union
Hydrology and

Earth System

Sciences

Discussions

Papers published in Hydrology and Earth System Sciences Discussions are under open-access review for the journal Hydrology and Earth System Sciences

\section{Parameter sensitivity to climate and landscape variability of a simple, lumped salt and water balance model}

M. A. Bari ${ }^{1,2}$ and K. R. J. Smettem ${ }^{3,4}$

${ }^{1}$ Department of Environment, 3 Plain Street, East Perth, W.A. 6004, Australia

${ }^{2}$ School of Earth and Geographical Sciences, Hydroscience Discipline Group, The University of Western Australia, 35 Stirling Highway, Crawley, W.A. 6009, Australia

${ }^{3}$ Centre for Water Research, The University of Western Australia 35 Stirling Highway, Crawley, W.A. 6009, Australia

${ }^{4}$ Cooperative Research Centre for Plant-Based Management of Dryland Salinity, The University of Western Australia, 35 Stirling Highway, Crawley, W.A. 6009, Australia

Received: 30 June 2005 - Accepted: 18 July 2005 - Published: 9 August 2005

Correspondence to: M. A. Bari (mohammed.bari@environment.wa.gov.au)

(C) 2005 Author(s). This work is licensed under a Creative Commons License.

\section{HESSD}

$2,1405-1447,2005$

Parameter sensitivity

of a salt and water

balance model

M. A. Bari and

K. R. J. Smettem

Title Page

Abstract

Introduction

Conclusions

References

Tables

Figures

14

-

Back

Full Screen / Esc

Print Version

Interactive Discussion

EGU 


\section{Abstract}

A salt and water balance model is developed to represent salinity generation following land use changes in Western Australia. The model consists of five interconnecting stores: (i) Dry, Wet and Subsurface unsaturated Stores, (ii) a transient Stream zone

5 Store and (iii) a saturated Groundwater Store. The salinity generation process in Western Australia is highly dependent on annual rainfall, potential energy for evaporation, salt fall and land use history of a catchment. We selected six experimental catchments with different land use histories across a climatic gradient to test the model and assess parameter sensitivity. The model was successful in representing the streamflow and salinity generation processes of all catchments. In the process of application, we classified the model parameters into three sets: (i) "known", (ii) "fixed" and (iii) "variable". The "known" parameter set is calculated a priori from catchment attributes. The "fixed" set comprises regionalised parameters that remain unchanged across all catchments once calibrated in one catchment. The "variable" set of seven physically meaningful pa15 rameters were calibrated at one catchment, estimated a priori for other catchments and then subsequently adjusted for best fit. The "variable" set represents: (i) the depth $(d)$, spatial distribution $(b, c)$, relationship of the lateral hydraulic conductivity with moisture content $(i a)$ and vertical conductivity $\left(K_{u v}\right)$ of the top soil, (ii) lateral conductivity $\left(K_{/ /}\right)$ of the groundwater system, and (iii) salt release $\left(C_{u}\right)$ from top soil. Sensitivity analyses of key model parameters show that the relationship of the top soil lateral hydraulic conductivity with soil moisture content $(i a)$ is the most sensitive parameter. Other sensitive parameters include the depth of the top soil and its spatial distribution $(d, b, c)$.

\section{Introduction}

Conceptual models that account for the continuous dynamics of hydrological processes were introduced in the early 1960s (Crawford and Linsley, 1962). As all models are approximations of the real world, model equations and parameters are ideal represen-
HESSD

$2,1405-1447,2005$

Parameter sensitivity

of a salt and water balance model

M. A. Bari and

K. R. J. Smettem

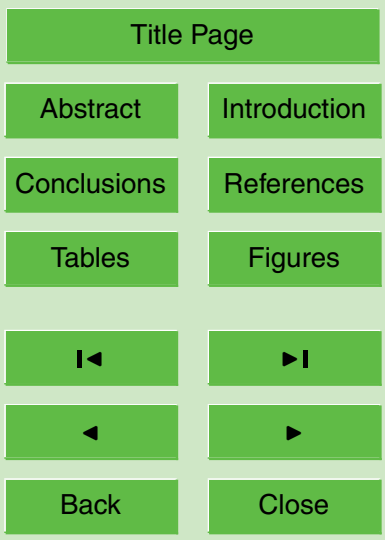

Full Screen / Esc

Print Version

Interactive Discussion

EGU 
tations of the landscape, which are not directly measurable. There are two approaches of estimating model parameters. The first approach (model calibration) adjusts model parameters so that the input-output (eg rainfall-runoff) response reasonably matches the observed responses. The second approach (a priori) estimates model parameters 5 through theoretical or empirical relationships with measurable catchment characteristics (e.g. soil and vegetation characteristics, geomorphology and topography). Manual and automated calibration techniques have been developed and widely used for estimating the model parameters (Duan, 2003; Wagner et al., 2003). Many sets of parameter values could be obtained that give acceptable model performance (Bevan and

10 Freer, 2001). Some of these parameter values could be "unrealistic", but still return a reasonable model performance principally due to: (i) the measurement errors and (ii) errors in the structure of the model (Bastidas et al., 2003; Kavetski et al., 2003; Gan and Biftu, 2003). A recent comparative assessment of 19 conceptual models, carried out on 429 catchments covering 4 continents, show that a large number of parameters do not 15 necessarily enhance model performance (Perrin et al., 2001). The authors argue that inadequate model complexity typically results in over parameterisation and parameter uncertainty. Their comparative study indicates that some models with a limited number of parameters can yield promising results and should be further developed. Most of the parameters of these models could ideally be estimated a priori. We adopted a new model building philosophy known as the "downward approach", originally proposed by Klemes (1983) in developing a simple salt and water balance model on a daily time step (Bari and Smettem, 2004; Bari et al., 2005; Bari and Smettem, 2005a, 2005b). Most of the parameters of the model are physically meaningful and can be correlated to directly measured data and other catchment attributes.

The principal objectives of this paper are to: (i) classify the model parameters into different sets that could be estimated a priori, (ii) perform sensitivity analysis of the key parameters, and (iii) identify physical significance of the sensitive parameter set. The model is applied to 6 experimental catchments with different land use history and climatic variability.

HESSD

$2,1405-1447,2005$

\section{Parameter sensitivity \\ of a salt and water balance model}

M. A. Bari and

K. R. J. Smettem

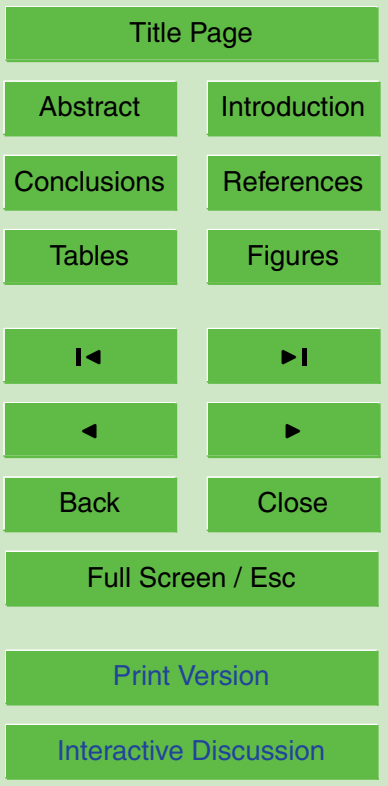

EGU 


\section{Hydrologic characteristics of the region}

HESSD

Salts originate from the ocean and are precipitated to the land with rainfall and dry fall out (Hingston and Gailitis, 1976). Part of the salt is transported via streamflow and the remainder is stored in the unsaturated zone. In the High Rainfall Zone (>1100 mmyr $\left.{ }^{-1}\right)$,

5 a permanent groundwater table lies within $2 \mathrm{~m}$ of the stream invert and a large amount of rainfall becomes streamflow (Bari and Smettem, 2004). As the streamflow is very high, it is fresh $\left(<500 \mathrm{mgL}^{-1} \mathrm{TDS}\right)$; salt storage in the unsaturated zone is very low; and the groundwater system is relatively fresh ( $\left.<1000 \mathrm{mgL}^{-1} \mathrm{TDS}\right)$. In the Intermediate Rainfall Zone $\left(1100-900 \mathrm{~mm} \mathrm{yr}^{-1}\right)$, salt storage is relatively high and groundwater is 10 generally brackish ( $2000 \mathrm{mgL}^{-1}$ TDS). As the streamflow is not enough to flush out all the incoming salt, additional salts accumulate in the soil profile. In the Low Rainfall Zone $\left(<900 \mathrm{~mm} \mathrm{yr}^{-1}\right)$, the groundwater tables lie far below the stream channel, salts are retained in the unsaturated zone as there appears to be no groundwater connection to the stream.

15 When a part of the landscape is cleared for agriculture, groundwater recharge increases mainly due to reduction in evapotranspiration. As the groundwater level increases, it dissolves the stored salt in the unsaturated zone (Bari and Smettem, 2005). Stream salinity does not increase dramatically until the rising groundwater system intersects the stream channel. The Low Rainfall Zone takes the longest time to show the effects of clearing on stream salinity, as the recharge rate is relatively low and the unsaturated storage deficit is large. For example, at the Lemon catchment stream salinity increased almost 20 fold and salt load increased in order of 80 fold when a small groundwater discharge area appeared (Mauger et al., 2001; Bari and Smettem, 2005b).

\section{Parameter sensitivity of a salt and water balance model}

M. A. Bari and

K. R. J. Smettem

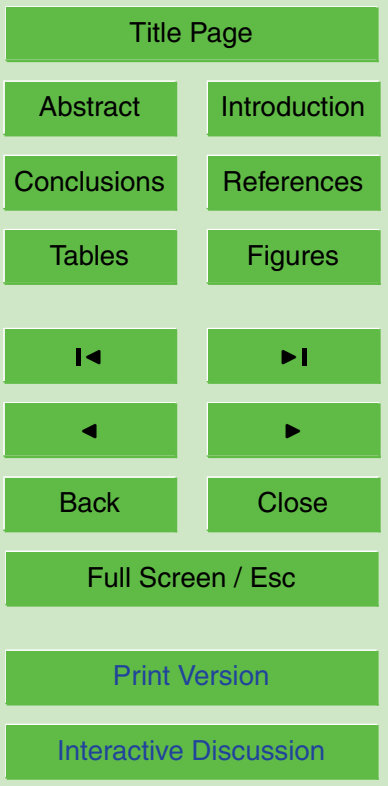




\section{Selection of experimental catchments}

Six experimental catchments selected are located in the Collie River catchment, southwest of Western Australia (Fig. 1). These experimental catchments are chosen based on their land use history and distribution across a climate gradient.

5 3.1. Control catchments

The two control catchments - Ernies and Salmon, were established in 1972 as a part of a comprehensive study relevant to the salinity generation process. Analyses of the groundwater data show that the permanent groundwater system seasonally connected to the stream at the Salmon catchment and mean annual runoff is about $11 \%$ of rainfall.

10 At the Ernies catchment the groundwater system did not play any role in the streamflow generation, as it was stable at about $20 \mathrm{~m}$ below the stream invert. Streamflow at the Ernies catchment was generated by saturation excess overland flow and interflow processes only (Bari and Smettem, 2005a,b). Salt storage was significantly higher (Table 1) and the annual stream salinity was lower than the Salmon catchment. Mean 15 annual runoff is about $1.2 \%$ of rainfall. The native vegetation is dominated by jarrah (Eucalyptus marginata), with marri (E. calophylla) and wandoo (E. wandoo) in both catchments.

\subsection{Cleared catchments}

Wights and Lemon are two experimental catchments, where native forest was cleared for agricultural development (Fig. 1). Both the catchments were established in 1972. Wights and Salmon catchments were set up as a pair and therefore characteristics were similar in terms of salt storage, groundwater system and runoff generation. Groundwater level at the Wights catchment rose systematically and the catchment achieved a new stability by 1986 when annual runoff coefficient increased to $38 \%$ 25 (Mauger et al., 2001; Bari and Smettem, 2004). Lemon was established as a pair
HESSD

2, 1405-1447, 2005

\section{Parameter sensitivity \\ of a salt and water balance model}

M. A. Bari and

K. R. J. Smettem

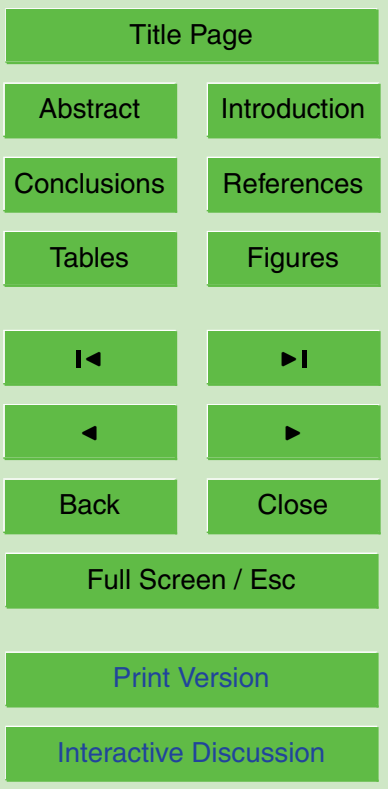

EGU 
with Ernies catchment (Fig. 1). Rainfall, pan evaporation, soil salt storage and other catchment characteristics were similar to the Ernies catchment (Table 1).

\subsection{Reforested catchments}

There are two experimental catchments - Maringee and Batalling Creek, where partial 5 reforestation took place in order to understand the effects of trees in lowering streamflow and salt load. Both the catchments are in the Low Rainfall Zone (Fig. 1). Due to clearing of native forest during 1960-1975, groundwater levels were increasing when reforestation was established (Bari and Croton, 2000). Groundwater salinity was high, some bore samples being in excess of $20000 \mathrm{mgL}^{-1}$ TDS. During 1981-1986, eu-

10 calyptus trees were planted along the stream zone covering 181 ha. Streamflow and salinity data are available from 1982 onward. The characteristics of Batalling Creek catchment are similar to the Maringee Farm catchment. The average salinity of the permanent groundwater was $12000 \mathrm{mgL}^{-1}$ TDS (Bari and Croton, 2002). During 1985-1986, eucalyptus trees were planted along the stream zone covering 342 ha. 15 Due to clearing of native forest, the catchment did not reach a new stability when trees were planted (Bari and Croton, 2002).

\section{The salt and water balance model}

A "downward approach", originally suggested by Klemes (1983) and recently followed by others (Jothityankoon et al., 2001; Farmer et al., 2003) was adopted in developing the salt and water balance model. At first the annual model was developed (Bari et al., 2005) and then elaborated for the monthly water balance (Bari and Smettem, 2004). Additional complexity was incorporated to represent the daily streamflow generation processes at an experimental catchment scale (Bari and Smettem, 2005a). The salt balance component was added subsequently (Bari and Smettem, 2005b). A catchment is represented by a hill slope and five connecting stores to describe different hydrolog-

\section{Parameter sensitivity of a salt and water balance model}

M. A. Bari and

K. R. J. Smettem

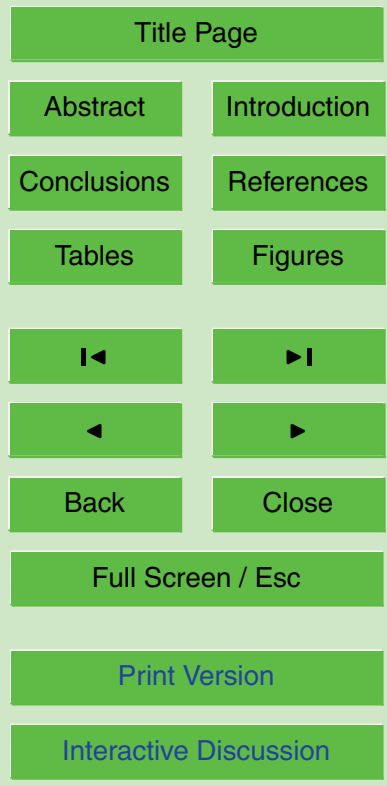

EGU 
ical processes. They are the Dry and Wet Stores, Stream zone Store, unsaturated Subsurface Store and Groundwater Store.

\subsection{Hydrological processes}

Evapotranspiration comprises interception, plant transpiration and soil evaporation. In5 terception is represented by a canopy store and is dependent on the Leaf Area Index. The rest of the rainfall reaches to the soil surface and either infiltrates or creates runoff. Some of the rainfall salt is intercepted on the plant leaves but then washed onto the soil surface in the subsequent events. Transpiration is predicted as a function of the Leaf Area Index, relative root volume in different Stores, moisture content and the potential energy (Bari and Smettem, 2004). Soil evaporation takes place from Dry and Wet Stores and Stream zone Store (Fig. 2).

Surface runoff is generated by the process of saturation excess $\left(Q_{r 1}\right)$ only, as the infiltration excess (Hortonian) overland flow is a rare event in Western Australia (Sharma et al., 1987). It is dependent upon the water content of the Wet Store and the variably contributing stream zone saturated areas (Fig. 3). If part of the stream zone is saturated by the presence of the permanent groundwater system, another component of surface runoff $\left(Q_{r 2}\right)$ is also generated. Interflow $\left(Q_{i}\right)$ is the contribution from the shallow, intermittent groundwater system. If the permanent groundwater system does not discharge to the stream, interflow controls the recession limb of the streamflow hydrograph. Interflow is a function of the catchment wide average lateral conductivity of the top soil and the water content of the Wet Store (Fig. 3).

Percolation $(I)$ is the amount of vertical water flow between the highly conductive top soil to the less conductive deep unsaturated soil profile (Fig. 2). It is controlled by the catchment-wide vertical hydraulic conductivity, water content in the Wet Store and the soil moisture deficit in the Subsurface Store. The deep-rooted trees use most of the percolated water for transpiration and very little reaches to the groundwater system. Recharge $(R I)$ to the Groundwater Store consists of matrix $\left(R I_{1}\right)$ and preferential flow $\left(R I_{2}\right)$ components. Baseflow to stream $\left(Q_{b}\right)$ is defined as the contribution of the per-

\section{Parameter sensitivity of a salt and water balance model}

M. A. Bari and

K. R. J. Smettem

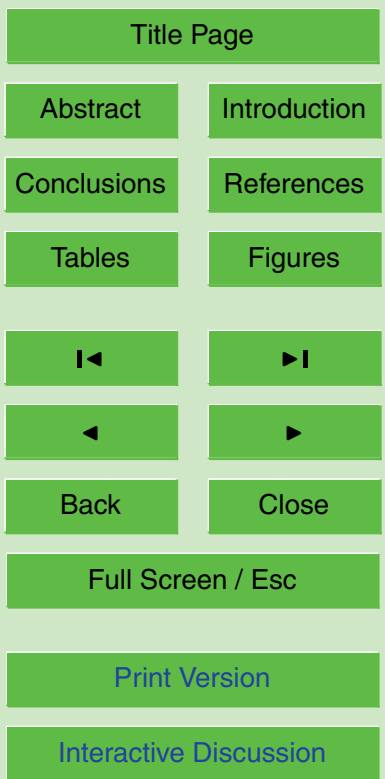

EGU 
manent groundwater system to streamflow. Baseflow is considered to be zero unless the groundwater system connects to the stream bed (Fig. 2). It is a function of the catchment-average lateral conductivity of the aquifer, slope of the groundwater system and stream length.

5 At present no surface or channel routing is incorporated into the model. This should not affect daily flow predictions as the areas of all the study catchments are less the $20 \mathrm{~km}^{2}$ (Table 1).

\subsection{Representation of the land use attributes}

There are two ways of representing the different types of land use within a catchment. 10 The first one is defined as the "catchment fraction". The salt and water balance in each of the five Stores is maintained in all "fractions". Except for the parameters related to the land uses (Leaf Area Index, root volume), the others are catchment averages. The second way of representing land use attributes is by "land use fractions". Within a "catchment fraction" there may be one or more "land use fractions". The area weighted average of LAI and root volume of different "land use fractions" are taken as the values for each "catchment fraction". Each of the "catchment fractions" has a separate mass balance for all five stores. Fig. 3b shows a hypothetical catchment where there are two "catchment fractions" - one consists of natural forests only while the other consists of two "land use fractions" - reforestation and pasture.

\section{Model application and discussion}

A very reasonable matching between the observed and predicted series was obtained despite different environmental settings and landuses (Table 1). For the control catchments, the first 5 years of data (1974-1978) was used for calibration and the rest for validation. Observed data during 1974-87 were used for the calibration of the model for cleared and reforested catchments. Methods of parameter estimation and statistical

HESSD

2, 1405-1447, 2005

Parameter sensitivity

of a salt and water balance model

M. A. Bari and

K. R. J. Smettem

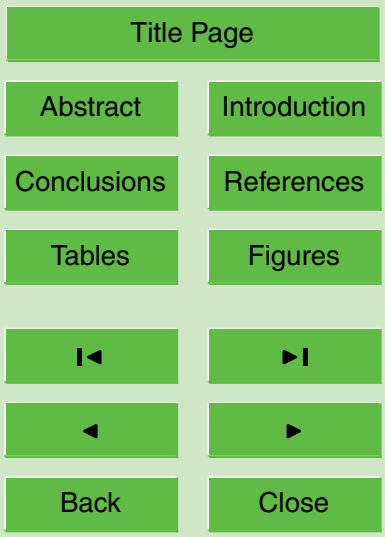

Full Screen / Esc

Print Version

Interactive Discussion

EGU 
An excellent fit between the observed daily streamflow, salinity and salt load was achieved at Salmon catchment during the period of study. The typical flow-period of the

5 Salmon catchment was from May to November. The daily stream salinity ranged from in excess of $500 \mathrm{mg} \mathrm{L}^{-1}$ TDS at the onset of streamflow in May to less than $200 \mathrm{mg} \mathrm{L}^{-1}$ TDS in July-August. Predicted daily streamflow and salt load was slightly higher and salinity was lower than observed in the period of May-June (Fig. 4). For the rest of the flow-period observed and predicted streamflow, salinity and salt load were very similar.

10 The flow-period and streamflow volume and salinity of Ernies catchment is much lower than that of Salmon (Fig. 5). The predicted daily peak flow and salt load matched very well. Most of the time the daily salt load was slightly under predicted, particularly during the period of recession, due to under prediction of daily streamflow.

Predicted dynamic saturated area along the stream zone was substantially higher at 15 Salmon catchment than at the Ernies catchment (Fig. 6). The saturated area ranged from less than $1 \%$ in dry summer months to, in some cases, more than $8 \%$ in wetwinter months. Stream zone saturated area during the summer was consistent with the measured data reported by Bari et al. (2005). The maximum saturated area at Ernies catchment was approximately $3 \%$ in 1983 (Fig. 6). The smaller saturated area 20 in combination with the low rainfall partially explains why the catchment generates significantly less streamflow than the Salmon catchment.

\subsection{Cleared catchments}

The monthly and daily model was applied to Lemon catchment in its developmental phase (Bari and Smettem, 2004; Bari and Smettem, 2005a,b). At Wights catchment, the groundwater system took less time after clearing compared to the Lemon catchment, to reach the stream invert and discharge to the stream. Since 1978 the stream

\section{Parameter sensitivity of a salt and water balance model}

M. A. Bari and

K. R. J. Smettem

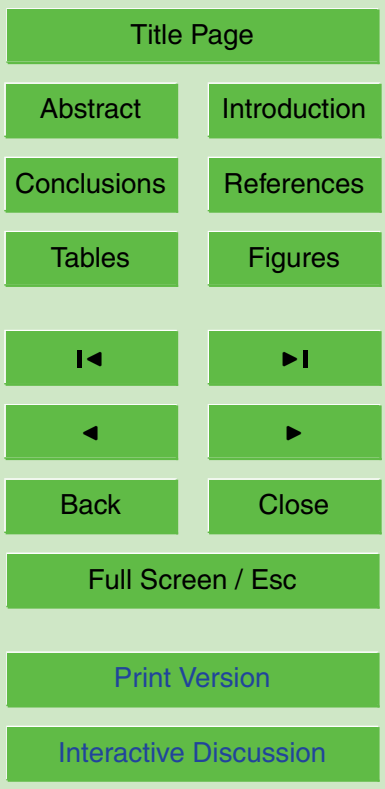

EGU 
started to flow for the whole year. Stream salinity increased compared to the Salmon control catchment but was significantly lower than the Lemon catchment. At the Wights catchment, daily salinity was in the order of $1000 \mathrm{mg} \mathrm{L}^{-1}$ TDS during November to May 1987, when baseflow was dominant. In the wet-winter months daily salinity was 5 reduced to approximately $500 \mathrm{mg} \mathrm{L}^{-1}$ TDS. The daily predicted salinity was slightly higher than observed during the winter-months (Fig. 7b). An excellent fit between the observed and predicted daily flow and load was observed.

\subsection{Reforested catchments}

The stream zones of both Maringee Farm and Batalling Creek catchments were highly saline and groundwater salt seeps were evident when reforested. Salinity in excess of $40000 \mathrm{mg} \mathrm{L}^{-1}$ TDS was observed when the catchments began to flow in MayJune. The model successfully reproduced the daily streamflow and salinity generation process of both the catchments. In 1987 annual rainfall was the lowest on record at Maringee Farm catchment and the flow-period for the observed and predicted daily flow was very similar (Fig. 8). The model tended to under predict daily peak flow and daily stream salinity, particularly during May-June and October-November when salinity exceeded $25000 \mathrm{mg} \mathrm{L}^{-1}$ TDS. This may be due to a disproportionate prediction of streamflow components, particularly the interflow and baseflow during this period. However, the predicted and observed salinity records matched very well during the 20 period when most of the streamflow occurred and led to a good predictions of the daily salt load hydrographs.

\subsection{Monthly streamflow and salinity}

The monthly predicted streamflow and salt load was compared against the observed data set. The model performance in terms of different statistical criteria as described in detail in Sect. 6.2. We present the scatter diagram of monthly streamflow and salt load obtained from Batalling Creek catchment (Fig. 9), the most salt affected catchment

HESSD

2, 1405-1447, 2005

Parameter sensitivity

of a salt and water balance model

M. A. Bari and

K. R. J. Smettem

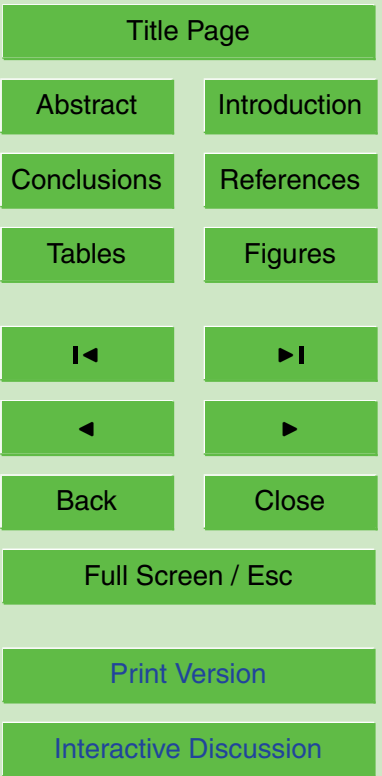

EGU 
located in the Low Rainfall Zone. There was a strong correlation between the observed and predicted monthly streamflow (Fig. 9a), but the relationship was relatively weaker for salt load (Fig. 9b). In March 1993, during the dry period, $115 \mathrm{~mm}$ of rain fell in two days and the catchment generated $760 \mathrm{~kg} \mathrm{ha}^{-1}$ salt load. The observed salinity 5 was in excess of $25000 \mathrm{mg} \mathrm{L}^{-1}$ TDS. The predicted salt load was $200 \mathrm{~kg} \mathrm{ha}^{-1}$. The other two significant out-liers were in June and July 1988 - a wet year followed by two successive very dry years. The observed and predicted salt loads were $600 \mathrm{~kg} \mathrm{ha}^{-1}$ and $1190 \mathrm{~kg} \mathrm{ha}^{-1}$ for June and $415 \mathrm{~kg} \mathrm{ha}^{-1}$ and $870 \mathrm{~kg} \mathrm{ha}^{-1}$ for July (Fig. 9b).

\subsection{Annual streamflow and salinity}

10 In some cases the model slightly over predicted the streamflow and salt load. Following clearing, streamflow of Wights catchment increased in the order of 3 fold and the salt load increased in the order of 10 fold. However, at Lemon catchment the streamflow and salt load increase was much higher than at Wights catchment. Average annual streamflow and salinity of Lemon catchment increased from its pre-clearing $20 \mathrm{~mm}$ and $80 \mathrm{mg} \mathrm{L}^{-1}$ TDS to $130 \mathrm{~mm}$ and $2300 \mathrm{mg} \mathrm{L}^{-1}$ TDS respectively when a new stability was achieved. Therefore the annual salt load of Lemon catchment increased 180 fold. The model represented the changes in stream salinity generation process very well. Mean annual salinity of Batalling Creek and Maringee Farm catchments are in the order of 5900 and $4700 \mathrm{mg} \mathrm{L}^{-1}$ TDS respectively. The predicted mean salinity for these two catchments were 5036 and $4987 \mathrm{mg} \mathrm{L}^{-1}$ TDS respectively (Table 2).

\section{Parameter estimation and model performance}

The model was successfully applied to six experimental catchments. The performance of the model was assessed against a range of statistical criteria and matching observed and predicted time series. There are two main approaches in estimating the model parameters. The first (a priori approach) estimates parameters by relying on empirical

HESSD

$2,1405-1447,2005$

Parameter sensitivity

of a salt and water balance model

M. A. Bari and

K. R. J. Smettem

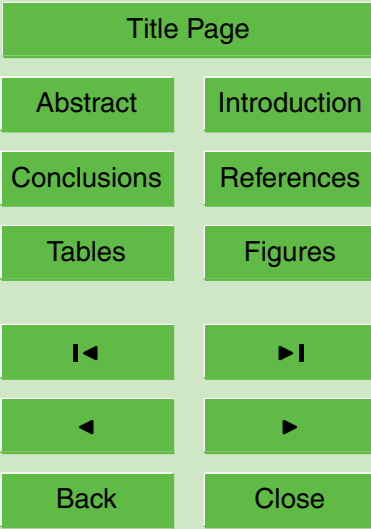

Full Screen / Esc

Print Version

Interactive Discussion

EGU 
relationships that relate to measurable or observable characteristics of a catchment, such as soil and vegetation properties, geomorphology and topographic features. The other (calibration) approach adjusts parameters, so that the input-output response of the model closely matches the observed responses (e.g. Rainfall-runoff). We followed 5 a combination of the two approaches. Most of the model parameters were estimated a priori. A group of 7 physically meaningful parameters, known as the "variable set" was initially estimated from a previous application and then adjusted to obtain the best model fit. The observed streamflow and salinity data was generally classified into two groups. The model was then calibrated for the one set of data and tested and verified 10 for the other set.

\subsection{Parameters estimated a priori}

This set of parameters was further classified into two groups: (i) "known" and (ii) "fixed" (Appendix A). The "known" parameter group is largely comprised of catchment attributes and is available, in most cases, from literature or can be obtained from field data. For example catchment average stream length, slope, depth to the permanent groundwater table and salt storage are available from existing records. Clearing of native forest, cropping pattern and reforestation were developed from historical land use data, areal photographs and talking to farmers.

The "fixed" parameter group was calibrated at the Ernies and Lemon catchments 20 and remained fixed for all other applications (Appendix A). For the Lemon catchment, streamflow data up to 1987 was used to capture the dynamic changes in the flow generation process due to clearing (Bari and Smettem, 2005a). There is no direct measurement of the parameters relevant to interception and soil evaporation processes. These parameters were calibrated so that the results are comparable to throughfall measurements undertaken elsewhere within the jarrah forest of Western Australia (Croton and Norton, 1998). Maximum Leaf Area Index and relative root volume in different stores were estimated from literature (Carbon et al., 1981). There was no measurement of the Leaf Area Index of pasture but values obtained from other successful model ap-

HESSD

$2,1405-1447,2005$

\section{Parameter sensitivity \\ of a salt and water balance model}

M. A. Bari and

K. R. J. Smettem

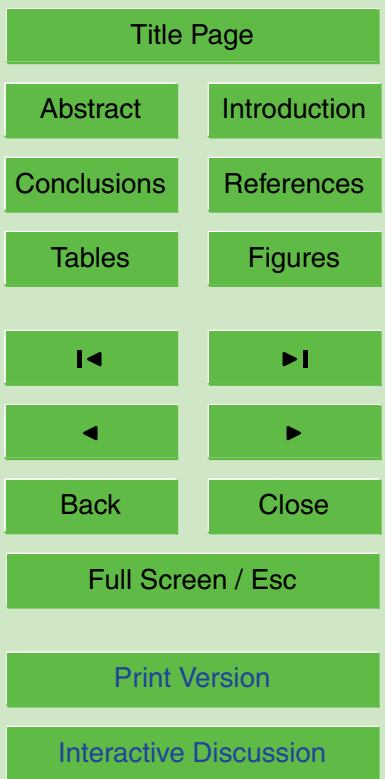

EGU 
plications were taken as input (Bari and Croton, 2000; Croton and Bari, 2001). Soil properties - catchment-wide average porosity, moisture content $(\theta)$ and field capacity $\left(\theta_{f}\right)$ were estimated from drilling information (Bari and Smettem, 2004). Indicative values of the lateral conductivity of top soil $\left(K_{u l}\right)$ and the vertical conductivity of the deep 5 unsaturated profile $\left(K_{/ v}\right)$ were obtained from literature (Sharma et al., 1987) and then calibrated at the Ernies and Lemon catchments.

\section{2. "Variable" parameter set}

The "variable" or catchment dependent parameters are those whose calibrated values may be markedly different from one catchment to another (Table 3). The depth of the 10 top soil and its spatial distribution was estimated from drilling information and other available literature. The average estimated depth of the top soil $(d)$ was $2500 \mathrm{~mm}$ for four out of six catchments. At Maringee and Batalling Creek catchments, the average depth of the top soil was lower, $2000 \mathrm{~mm}$ and $1900 \mathrm{~mm}$ respectively (Table 3). Two parameters $(b, c)$, responsible for the spatial distribution of the water holding capacity of the top soil, were initially obtained from literature (Sivapalan and Woods, 1995) and then adjusted from best fit. For most of the catchments these two parameters remained unchanged (Table 3).

The vertical hydraulic conductivity $\left(K_{u v}\right)$ of the top soil and non-linear relationship of the lateral hydraulic conductivity with soil moisture content $(i a)$ are the two parameters 20 whose calibrated values were different from one catchment to another (Table 3). Lateral hydraulic conductivity of the deep clay profile $\left(K_{/ I}\right)$ controls the baseflow, stream zone saturated areas and salt load to the stream. Except for the Lemon catchment, calibrated values were similar across all catchments. Sharma et al. (1987) reported that the hydraulic conductivity of the surface soil is in the range of $200-400 \mathrm{~mm} \mathrm{day}^{-1}$. All the estimates were reasonably consistent with that finding.

One parameter $\left(C_{u}\right)$ controls the release of salt from Dry to Wet Store. Salt in these two stores is obtained from drilling logs and salinity of the shallow bores. Once calibrated at the Ernies catchment, it was transferred to other catchments and then ad-

\section{Parameter sensitivity of a salt and water balance model}

M. A. Bari and

K. R. J. Smettem

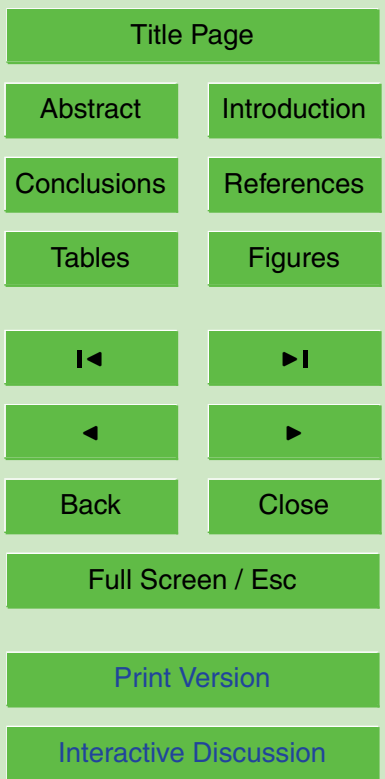

EGU 
justed based on the stability of the salt content of the Dry Store and matching of the observed and predicted stream salinity. In three out of six catchments, the value of this parameter remained identical (Table 3).

\subsection{Model performance criteria}

5 A standard set of criteria has been defined with the sole purpose of measuring how closely the model predicted daily series (flow and salt load) agrees with the measured series. The standard set of performance criteria comprises of: (a) joint plots of simulated and observed daily series, (b) scatter diagram of monthly and annual series, (c) flow-period Error Index $(E I)$, (d) Nash-Sutcliffe Efficiency $\left(E^{2}\right)$, (e) Explained Variance $10(E V)$, (f) Correlation Coefficient $(C C)$ and $(\mathrm{g})$ Overall water and salt balances $(E)$.

The flow-period error index $(E I)$ provides a numerical measure of the difference between the flow periods of simulated and observed daily flows:

$E I=1-\frac{\int\left[f_{o}(q)-f_{m}(q)\right] d q}{\int f_{o}(q) d q}$

In the above equation, $f_{o}(q)$ and $f_{m}(q)$ are the flow-period (number of days without zero

flow) of the observed and predicted daily series.

The Nash-Sutcliffe Efficiency $\left(E^{2}\right)$ is computed on the basis of the sequence of observed monthly flows and salt loads (Nash and Sutcliffe, 1970). It is computed as:

$$
E^{2}=\frac{\frac{1}{n} \sum_{i=1}^{n}\left(q_{o i}-\overline{q_{o}}\right)^{2}-\frac{1}{n} \sum_{i=1}^{n}\left(q_{o i}-q_{m i}\right)^{2}}{\frac{1}{n} \sum_{i=1}^{n}\left(q_{o i}-\overline{q_{o}}\right)^{2}}
$$

Where $n$ is the total number of records during the simulation period, $q_{m i}$ - simulated 20 monthly flow, $q_{o i}$ - observed monthly flow and $\overline{q_{O}}$ is the average observed monthly flow over the whole simulation period.

Parameter sensitivity

of a salt and water balance model

M. A. Bari and

K. R. J. Smettem

Title Page

Abstract

Introduction

Conclusions

References

Tables

Figures

14

$\rightarrow$

$\triangleleft$

Back

Close

Full Screen / Esc

Print Version

Interactive Discussion

EGU 
Explained variance coefficient $(E V)$ is another measure of performance of the model prediction against the observed series. It can be written as:

$$
E V=1-\frac{\frac{1}{n} \sum_{i=1}^{n}\left(\varepsilon_{i}-\bar{\varepsilon}\right)^{2}}{\frac{1}{n} \sum_{i=1}^{n}\left(q_{o i}-\overline{q_{o}}\right)^{2}}
$$

In the above equation, $\varepsilon_{i}=q_{o i}-q_{m i}$ is the error in prediction and $\bar{\varepsilon}$ is the mean of errors 5 during the whole period of simulation.

The Correlation Coefficient $(C C)$ is another statistical criteria to see how the model predicted streamflow and salt load series match with the measured series. It is computed as (for perfect fit $C C$ is 1 ):

$$
C C=\frac{\sum_{i=1}^{n}\left(q_{o i}-\bar{q}_{o}\right)\left(q_{m i}-\bar{q}_{m}\right)}{\left[\sum_{i=1}^{n}\left(q_{o i}-\bar{q}_{o}\right)^{2} \sum_{i=1}^{n}\left(q_{m i}-\bar{q}_{m}\right)^{2}\right]^{0.5}}
$$

10 In the above equation, $\overline{q_{o}}$ and $\overline{q_{m}}$ are the mean of the monthly observed and predicted flow for the whole period of record.

The water and salt balance error $(E)$ is computed in the model as the deviation of predicted volumes $\left(Q_{m}\right)$ from the observed series $\left(Q_{o}\right)$ for the whole period of record (WMO, 1986). It is formulated as:

${ }_{15} E=\frac{Q_{m}-Q_{0}}{Q_{0}}$

\subsection{Model performance}

Performance of the model based on the joint plots of daily streamflow salinity and salt load data was determined by matching the observed and predicted series. It was

\section{Parameter sensitivity of a salt and water balance model}

M. A. Bari and

K. R. J. Smettem

\section{Title Page}

Abstract Introduction

Conclusions References

Tables

Figures

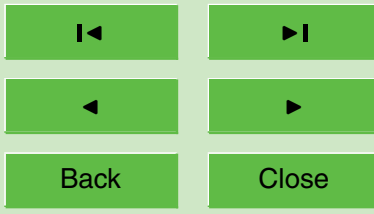

Full Screen / Esc

Print Version

Interactive Discussion

EGU 
primarily dependent upon the subjective judgement of the modeller. However, each of the five numerical criteria gave a more stringent test of the performance of the model (Table 4). Except for the Lemon and Batalling Creek catchments, the flow-period of the predicted streamflow was longer than observed for all other catchments (Table 4a). The 5 model application at the Maringee Farm catchment produced the highest Correlation Coefficient $(C C)$ while the Salmon catchment had the lowest Nash-Sutcliffe Efficiency $\left(E^{2}\right)$. The model had a tendency of over predicting total flow volume during the study period for all catchments (Table 4a). The goodness of fit for stream salt load predictions was similar to the streamflow prediction (Table $4 b)$. The Nash-Sutcliffe Efficiency $\left(E^{2}\right)$ 10 was lowest at the Maringee Farm while the Correlation Coefficient $(C C)$ was highest for the Ernies catchment. The salt balance error index $(E)$ shows that except for the Lemon catchment, over all salt prediction was slightly higher than observed at all other catchments (Table $4 b$ ).

\subsection{Sensitivity of key parameters}

15 We conducted sensitivity analyses to evaluate the model performance. The "variable" parameter set was selected because they generally require adjustment to obtain a good fit (Appendix A). The value of each of the parameters was systematically changed by $\pm 20 \%$ of the calibrated values. We selected Batalling Creek catchment as it: (i) is located in the Low Rainfall Zone, which is the most difficult zone to calibrate, (ii) 20 is partially cleared and salt affected and (iii) has trees planted covering $19 \%$ of the catchment area. The daily streamflow for 1995 was chosen as an example, as it was a typical flow year. The impact of these parameter changes is assessed in annual streamflow and salinity volumes. Relative sensitivity of a particular parameter $(S R)$ is defined by a function. A similar function was also used by Vertessy et al. (1993) and can be described as:

$S R=\frac{\Delta Q / Q_{a m}}{\Delta P / P_{m}}$

\section{Parameter sensitivity of a salt and water balance model}

M. A. Bari and

K. R. J. Smettem

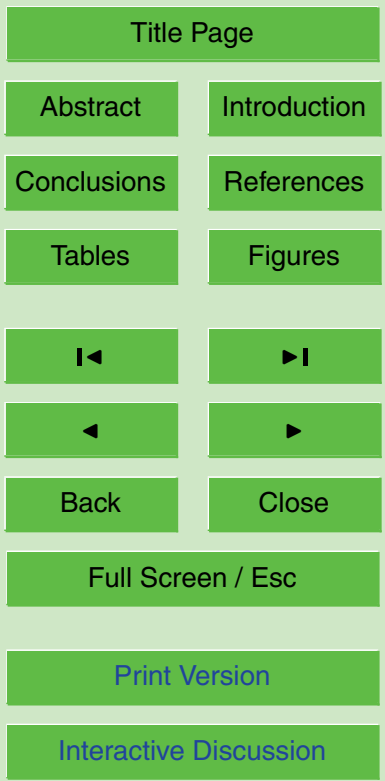

EGU 
In the above equation $\Delta Q$ is the change in annual streamflow or salt load for 1995 from the calibrated value $Q_{a m}$ and $\Delta P$ is the absolute change in a parameter from the calibrated value of $P_{m}$.

The relative sensitivity of the "variable" parameter set in terms of water and salt 5 balance is ranked (one being the most sensitive). The relationship of the catchment average lateral conductivity of the top soil with moisture content $(i a)$ is the most sensitive parameter (Table 5). Reduction of the calibrated value by $20 \%$ increases the streamflow and reduces the salt. The peak flow and interflow components increased significantly (Fig. 10b) and there was a reduction in stream salinity for the whole flow10 period (Fig. 11a). The daily salt load increased during the recession period and decreased during the peak flow periods compared to the calibration. The increase in annual streamflow was $71 \%$ and reduction in salt load was $13 \%$ (Fig. 12). Increasing the parameter value from 2.5 to 3 reduced the streamflow volume by $25 \%$ and increased the salt load by $1 \%$.

Reducing the vertical hydraulic conductivity of the top soil $\left(K_{u v}\right)$ increases the annual streamflow, reduces the salt load and vice versa (Table 5). Increasing the vertical hydraulic conductivity $\left(K_{u v}\right)$ by $20 \%$ led to a decrease in streamflow volume of $13 \%$ and an increase in salt load volume of $4 \%$ (Fig. 12). Reduction in vertical conductivity increased the interflow (Fig. 10b) and reduced the salinity (Fig. 11b). Overall the daily stream salt load increased during the recession and decreased during the peak flow periods.

The next two most sensitive parameters were the average depth of the top soil $(d)$ and the parameter responsible for the spatial distribution of the water holding capacity of the top soil $(b)$. Both of these two parameters have direct effect on the daily flow and salt load. Increasing the average depth of the top soil $(d)$ resulted in a decrease in peak flow and a slight increase in both the interflow component and salinity. Increasing the parameter $b$ by $20 \%$ resulted in an increase in the peak flow and daily salinity. Therefore, the annual salt load and flow increased by $8 \%$ and $7 \%$ respectively. Changes in the depth of the top soil $(d)$ have a relatively large impact on the annual salt load than

HESSD

$2,1405-1447,2005$

\section{Parameter sensitivity \\ of a salt and water balance model}

M. A. Bari and

K. R. J. Smettem

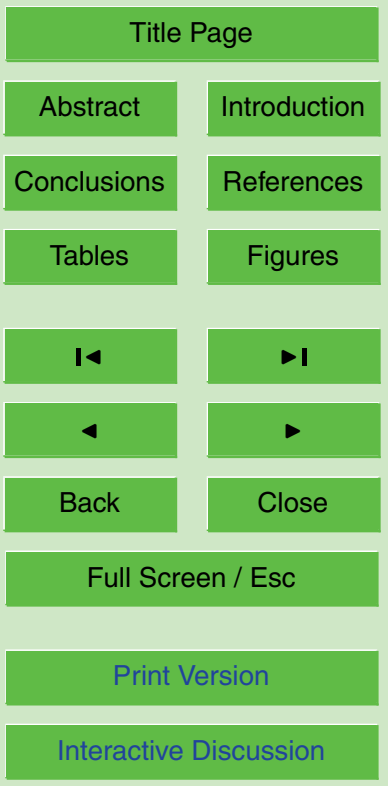

EGU 
the flow volume (Table 5).

Another sensitive parameter was the lateral hydraulic conductivity of the saturated layer $\left(K_{/ /}\right)$. Changes in lateral hydraulic conductivity $\left(K_{/ /}\right)$had little effect on the shape of the flow hydrograph and had the highest increase in daily salinity (Fig. 11a) and 5 therefore salt load (Fig. 12b). Decreasing the lateral conductivity by $20 \%$ (from 400 to $320 \mathrm{~mm} \mathrm{day}^{-1}$ ) resulted in an annual salt load and streamflow decrease of $18 \%$ and $1 \%$ respectively.

The other parameter, related to the water holding capacity of the top soil $(c)$, had a relatively minor impact on streamflow and salt load (Table 5). The parameter re10 sponsible for the salt balance of the Dry Store $\left(C_{u}\right)$ has no effect on the water balance and negligible impact on the salinity if the groundwater system reaches the stream bed (Table 5). However, this parameter has a significant impact on the stream salinity of catchments where the permanent groundwater system does not play any role in flow generation process for example Ernies catchment.

\section{Physical significance of parameters and discussion}

\subsection{Evapotranspiration}

Evapotranspiration is composed of soil evaporation, interception and plant transpiration. In our model the soil evaporation is considered as a non-linear function of the potential energy, soil moisture content, leaf surface store and through fall. Interception by the plant canopy is dependent on leaf surface store. Plant transpiration is characterised by the relative root volumes in different stores, Leaf Area Index, potential energy and moisture content. The relative root volume in different stores is simply the proportion of roots and not the actual volume of roots for pasture or native forest. Once calibrated at Ernies catchment, all the parameter related to evapotranspiration remained unchanged across all catchments (Appendix A).

\section{HESSD}

2, 1405-1447, 2005

Parameter sensitivity

of a salt and water balance model

M. A. Bari and

K. R. J. Smettem

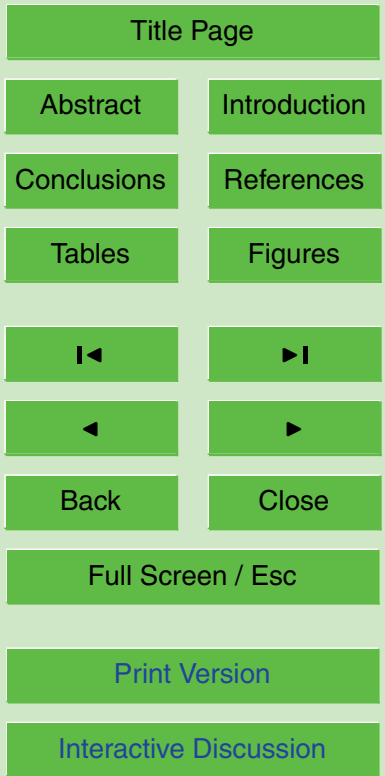


The variably contributing saturated areas generate surface runoff. Similar concepts of variable contributing areas were also used in other catchment models, such as ARNO (Todini, 1996), TOPMODEL (Beven and Kirkby, 1979), XINANJIANG (Zhao and Liu,

5 1995), and VIC (Wood et al., 1992). Most of these models used a simple probability distribution of the soil moisture content to represent dynamic variation of the contributing areas within a catchment. The soil moisture storage is directly related to the distribution of soil depth and porosity. In this study, mean depth of the top soil is $2500 \mathrm{~mm}$ for most of the catchments, but lower for Maringee Farm and Batalling Creek catch10 ments (Table 4). The distribution of the top soil depth and its water holding capacity is controlled by two parameters $(b, c)$. In most of the applications these two parameters remained identical (Table 4 ). Relative sensitivity analysis shows that the parameter $c$ is least sensitive (Table 5). More work is necessary to see if those two parameters can be reduced to one.

15 7.3. Interflow and percolation

Due to the dynamic variation of the stream zone saturated areas, a perched water table is formed during the wet period of the year. The interflow is then an important process in hydrological models because it affects the extent of the variably saturated area, the soil moisture storage and also controls hydrograph recession limbs. The 20 catchment-average lateral hydraulic conductivity at saturation $\left(K_{u l}\right)$ remained identical (approximately $400 \mathrm{~mm}$ day $^{-1}$ ) for all catchments. A similar value was also calibrated for the monthly version of the model (Bari and Smettem, 2004). A recent application of a distributed catchment model to some of the catchments shows that the lateral conductivity of the top soil may be very high, in excess of $5 \mathrm{~m} \mathrm{day}^{-1}$ (Bari and Croton, 25 2002; Croton and Bari, 2001; Bari and Croton, 2000). However, due to the probability distribution of the moisture content of the top soil, there is always depletion, redistribution and transfer of water from the upper part of the landscape to the lower stream

\section{Parameter sensitivity of a salt and water balance model}

M. A. Bari and

K. R. J. Smettem

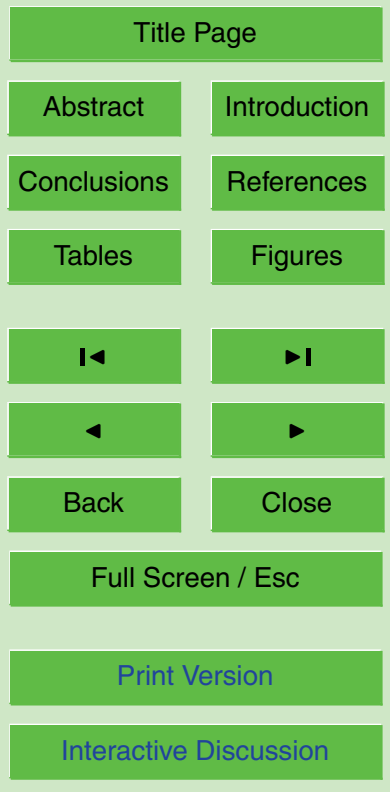

EGU 
zone. The parameter (ia), responsible of the non-linear relationship of lateral conductivity with moisture content, was variable from one catchment to another (Table 4), and was found to be the most sensitive parameter (Table 5). The interflow equation is very similar to the one developed by Avarjenov (1950). Percolation loss from the 5 top soil feeds the deep unsaturated profile and ultimately the Groundwater Store. The catchment-wide average vertical hydraulic conductivity $\left(K_{u v}\right)$ at saturation remained identical in most of the catchments (Table 3 ). The preferential flow from the top soil is incorporated into the model by two parameters $(p b, p a)$ and the moisture content of the lower unsaturated profile. The percolation also depends on moisture content of the 10 Wet Store. In practice, these flux related parameters are the most difficult and expensive to measure independently. Field measurements may yield initial indicative values but the catchment scale estimates should be achieved through calibration.

\subsection{Recharge and baseflow}

Recharge from the unsaturated profile to the groundwater system may occur by two 15 processes - matrix and preferential flow. The thickness of the profile and porosity was calculated from drilling information. The preferential flow depends upon the average vertical conductivity and moisture content. The function is similar to the one described by Averjanov (1950). Average thickness of the groundwater system and porosity determine the store value. If the Groundwater Store is connected to the stream bed, 20 baseflow $\left(Q_{b}\right)$ is calculated as a function of lateral hydraulic conductivity of the aquifer and average slope. Except the Lemon catchment, lateral hydraulic conductivity $\left(K_{/ /}\right)$of most of the catchments was similar (Table 3).

The salinity related parameter $\left(C_{u}\right)$ represents the complex chemical processes of adsorption, convection and diffusion. It is not practically possible to measure this parameter in the field. Once calibrated, the identical value was used for releasing salt from the deep unsaturated profile to the groundwater system by recharge and preferential flow. However, when the groundwater level rises, it dissolves all the salt from the "occupied" unsaturated zone. Salt in the Groundwater Store is always assumed to be

\section{Parameter sensitivity of a salt and water balance model}

M. A. Bari and

K. R. J. Smettem

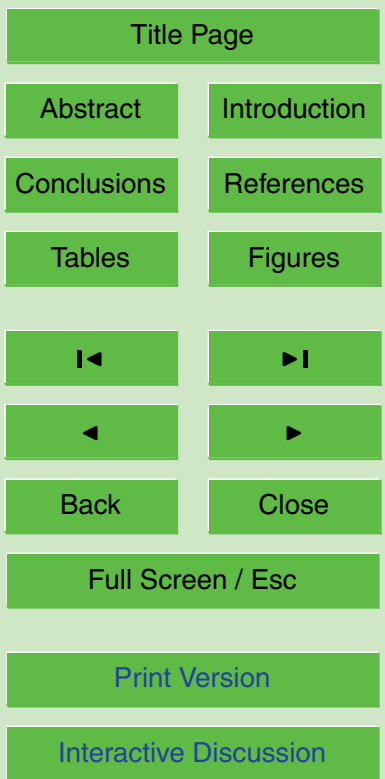

EGU 


\section{Summary and conclusion}

The catchment water and salt balance model has been tested and validated at six experimental catchments across a climatic gradient with different environmental and land use settings. The model performance was excellent in representing the changes in hydrological and salinity generation processes following land use change. The matching of the observed and predicted daily streamflow, salinity and salt load for all catchments was very good. The model successfully predicted the timing of the rise of the groundwater system following clearing and the creation of the saturated areas along the stream zone. Most of the catchment attributes readily available from literature were incorporated into the model. A key finding is that a large number of these parameters remained identical across all six catchments, and needed no change in values from one catchment to another to achieve best model performance.

There is a set of seven parameters that needs to be adjusted from one catchment to another to obtain the best fit. Those parameters are related to: (i) the depth and spatial distribution of top soil, (ii) catchment average lateral and vertical hydraulic conductivity and its non-linear relationship with moisture content, (iii) lateral hydraulic conductivity of the groundwater system, and (iv) salt release from top soil.

Relative sensitivity analyses of key parameters show that the vertical hydraulic conductivity of the top soil and the relationship of the lateral hydraulic conductivity with soil moisture content are the most sensitive parameters. Other sensitive parameters include the catchment-wide average lateral conductivity of the saturated aquifer and the depth and spatial distribution of the top soil.

\section{Parameter sensitivity of a salt and water balance model}

M. A. Bari and

K. R. J. Smettem

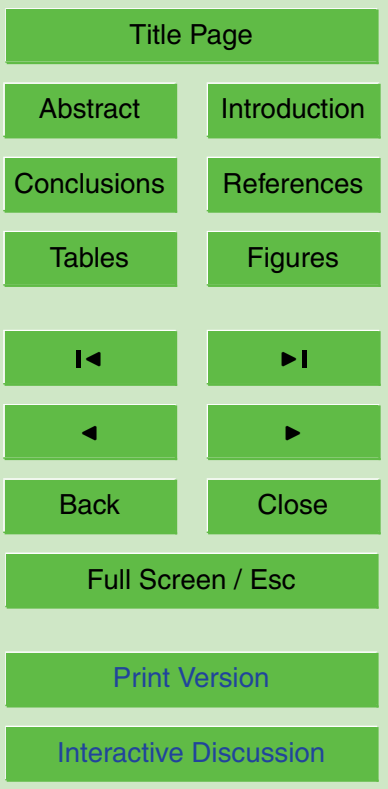




\section{References}

Averjanov, S. F.: About permeability of subsurface soils in case of incomplete saturation, Engr. Collect., 7, 19-21, 1950.

Bari, M. A. and Croton, J. T.: Predicting the impacts of land use changes on streamflow and salinity by a fully distributed catchment model, in: Hydro2000, Third International Hydrology and Water resources Symposium, The Institution of Engineers, Australia, 311-316, 2000.

Bari, M. A. and Croton, J. T.: Assessing the effects of valley reforestation on streamflow and salinity using the WEC-C model, in: Hydrology 2002, 27th Hydrology and Water resources Symposium, The Institution of Engineers, Australia, 176pp, 2002.

Bari, M. A., Smettem, K. R. J., and Sivapalan, M.: Understanding changes in annual runoff following land use changes: a systematic data-based approach, Hydrol. Processes, in press, 2005.

Bari, M. A. and Smettem, K. R. J.: Modelling monthly runoff generation processes following land use changes: groundwater-surface runoff interactions, Hydrol. Earth Syst. Sci., 8(5), 903-922, 2004 SRef-ID: 1607-7938/hess/2004-8-903.

Bari, M. A. and Smettem, K. R. J.: A daily water balance model for representing streamflow generation process following landuse change, Hydrol. Earth Syst. Sci. Discuss., 2, 821-861, $2005 a$,

20 SRef-ID: 1812-2116/hessd/2005-2-821.

Bari, M. A. and Smettem, K. R. J.: A daily salt balance model for representing streamflow generation process following landuse change, Hydrol. Earth Syst. Sci. Discuss., 2, 11471183, 2005b,

SRef-ID: 1812-2116/hessd/2005-2-1147.

Bastidas, L., Gupta, H. V., Hsu, K., and Sorooshian, S.: Parameter, structure and model performance evaluation for land surface schemes, in: Calibration of Watershed Models, edited by: Duan, Q., Gupta, H. V., Sorooshian, S., Rousseau, A. N., and Turcotte, R., 229-237, 2003.

Beven, K. J. and Kirkby, M. J.: A physically-based variable contributing area model for basin hydrology, Hydrol. Sci. Bull., 24(1), 43-69, 1979.

30 Beven, K. J. and Freer, J.: Equifinality, data assimilation, and uncertainty estimation in mechanistic modelling of complex environmental systems using the GLUE methodology, J. Hydrol., 249, 11-29, 2001.

\section{HESSD}

2, 1405-1447, 2005

Parameter sensitivity

of a salt and water balance model

M. A. Bari and

K. R. J. Smettem

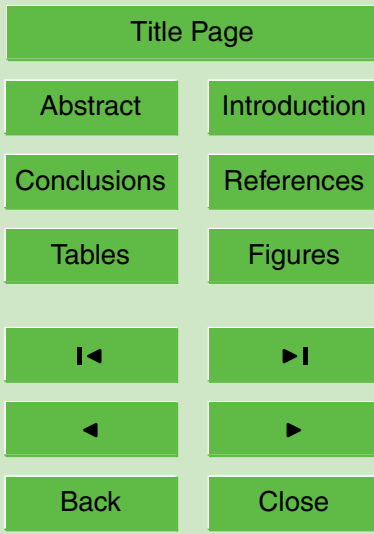

Full Screen / Esc

Print Version

Interactive Discussion 
Carbon, B. A., Bartle, G. A., and Murray, A. M.: Patterns of water stress and transpiration in jarrah (Eucalyptus marginata Don Ex Sm.) forests, Aust. Forest. Res., 11, 191-200, 1981.

Crawford, N. H. and Linsley, R. K.: Digital simulation in hydrology - Stanford Watershed Model IV, Technical Report No. 39, Department of Civil Engineering, Stanford University, Stanford, 5 CA, 1966.

Croton, J. T. and Norton, S. M. G.: Rainfall interception in the Northern jarrah forest of Western Australia. Water and Rivers Commission, Water Resources Tech. Series No. WRT-17, 28pp., 1998.

Croton, J. T. and Barry, D. A.: WEC-C: A fully distributed, deterministic catchment model10 foundation, formation, testing and application, Environmental Modelling and Software, 16, 583-599, 2001.

Duan, Q.: Global optimization for watershed model calibration, in: Calibration of watershed models, Water science and application 6, edited by: Duan, Q., Gupta, H. V., Sorooshian, S., Rousseau, A. N., and Turcotte, R., American Geophysical Union, Washington D.C., 89-104, 2003.

Farmer, D. L., Sivapalan, M., and Jothityangkoon, C.: Climate, soil and vegetation controls upon the variability of water balance in temperate and semi-arid landscapes: Downward approach to hydrological prediction, Water Resour. Res., 39(2),1035-1055, doi:10.1029/2001WR000328, 2003.

20 Gan, T. Y. and Biftu, G. T.: Effects of model complexity and structure, parameter interactions and data on watershed modelling, in: Calibration of Watershed Models, edited by: Duan, Q., Gupta, H. V., Sorooshian, S., Rousseau, A. N., and Turcotte, R., 317-329, 2003.

Gupta, H. V., Sorooshian, S., Hogue, T. S., and Boyle, D. P.: Advances in automatic calibration of watershed models, in: Calibration of watershed models, Water science and application 6, edited by: Duan, Q., Gupta, H. V., Sorooshian, S., Rousseau, A. N., and Turcotte, R., American Geophysical Union, Washington D.C., 9-28, 2003.

Jothityangkoon, C., Sivapalan, M., and Farmer, D. L.: Process controls of water balance variability in a large semi-arid catchment: Downward approach to hydrological model development, J. Hydrol., 254(1-4), 174-198, 2001.

so Kavetski, D., Fransk, S. W., and Kuczera, G.: Confronting input uncertainty in environmental modelling, in: Calibration of Watershed Models, edited by: Duan, Q., Gupta, H. V., Sorooshian, S., Rousseau, A. N., and Turcotte, R., 49-68, 2003.

Klemes, V.: Conceptualisation and scale in hydrology, J. Hydrol., 65, 1-23, 1983.

HESSD

2, 1405-1447, 2005

\section{Parameter sensitivity \\ of a salt and water balance model}

M. A. Bari and

K. R. J. Smettem

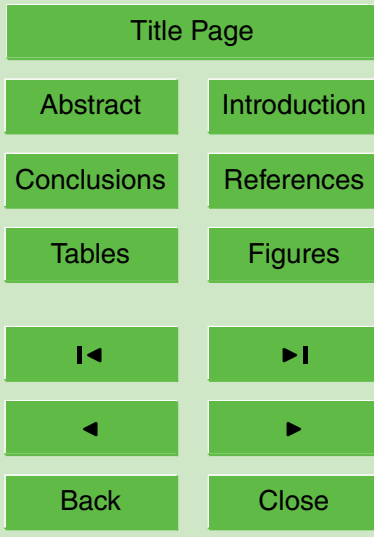

Full Screen / Esc

Print Version

Interactive Discussion 
Mauger, G. W., Bari, M. A., Boniecka, L., Dixon, R. N. M., Dogramaci, S. S., and Platt, J.: Salinity Situation Statement: Collie River, Water and Rivers Commission, Water Resource Technical Series No. WRT 29, 106p., 2001.

Nash, I. E. and Sutcliffe, I. V.: River flow forecasting through conceptual models, I. J. Hydrol., 5 10, 282-290, 1970.

Perrin, C., Michel, C., and Andreassian, V.: Does a large number of parameters enhance model performance? Comparative assessment of common catchment model structures on 429 catchments, J. Hydrol., 242, 275-301, 2001.

Sivapalan, M. and Woods, R. A.: Evaluation of the effects of general circulation models' subgrid variability and patchiness of rainfall and soil moisture on land surface water balance fluxes, Hydrol. Process., 9, 453-473, 1995.

Todini, E.: The ARNO rainfall-runoff model, J. Hydrol., 175, 339-382, 1996.

Vertessy, R. A., Hutton, T. J., O'Shaughnessy, P. J., and Jayasuriya, M. D. A.: Predicting water yield from a mountain ash forest using a terrain analysis based catchment model, J. Hydrol., 150, 284-298, 1993.

Wagner, T., Wheater, H. W., and Gupta, H. V.: Identification and evaluation of watershed models, in: Calibration of watershed models, Water science and application 6, edited by: Duan, Q., Gupta, H.V., Sorooshian, S., Rousseau, A. N., and Turcotte, R., American Geophysical Union, Washington D.C., 29-47, 2003.

WMO: Inter-comparison of models of snowmelt runoff. Operational Hydrology Report No. 23, World Meteorological Organization, Geneva, 1986.

Wood, F. F., Lettenmaier, D. P., and Zartarian, V. G.: A land-surface hydrology parameterization with subgrid variability for general circulation models, J. Geophys. Res., 97, 2717-2728, 1992.

Zhao, R. J. and Liu, X. R.: The Xinanjiang model, in: Computer Models of Watershed Hydrology, edited by: Singh, V. P., Water Resources Publications, Littleton, Colorado, 215-232, 1995.

Parameter sensitivity

of a salt and water balance model

M. A. Bari and

K. R. J. Smettem

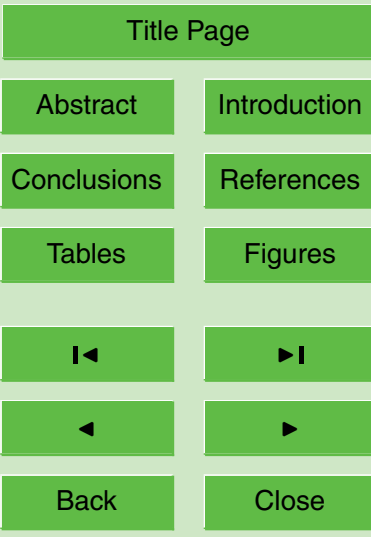

Full Screen / Esc

Print Version

Interactive Discussion 
2, 1405-1447, 2005

Table 1. Catchment attributes.

\begin{tabular}{lcccccc}
\hline Catchment attribute & Salmon & Wights & Ernies & Lemon & Maringee & Batalling \\
\hline Area (ha) & 82 & 94 & 270 & 344 & 1275 & 1639 \\
Pan evaporation (mm) & 1350 & 1350 & 1600 & 1600 & 1650 & 1625 \\
Rainfall $\left(\mathrm{mm} \mathrm{yr}^{-1}\right)$ & 1100 & 970 & 710 & 710 & 625 & 650 \\
Rainfall salinity $\left(\mathrm{mg} \mathrm{L}^{-1}\right)$ & 10 & 10 & 8.8 & 8.8 & 7.3 & 6.7 \\
Groundwater depth (m) & 3.2 & 4.4 & 18.0 & 18.0 & 5.0 & 5.0 \\
Salt storage $\left(\mathrm{kg} \mathrm{m}^{-3}\right)$ & 0.6 & 0.6 & 2.3 & 2.3 & 4.8 & 6.2 \\
Average slope $(\%)$ & 6 & 15 & 5 & 12 & 8 & 4 \\
Stream length (m) & 500 & 700 & 1100 & 1200 & 7200 & 9200 \\
Natural forest (\%) & 100 & Nil & 100 & 46 & 45 & 49 \\
Pasture (\%) & Nil & 100 & Nil & 54 & 43 & 32 \\
Reforestation (\%) & Nil & Nil & Nil & Nil & 12 & 19 \\
\hline
\end{tabular}

Parameter sensitivity

of a salt and water balance model

M. A. Bari and

K. R. J. Smettem

\section{Title Page}

Abstract

Conclusions
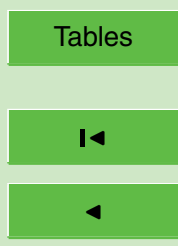

Back
Introduction

References

Figures

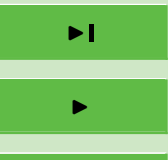

Close

Full Screen / Esc

Print Version

Interactive Discussion

EGU 
2, 1405-1447, 2005

Table 2. Mean annual observed and predicted streamflow and salinity.

\begin{tabular}{|c|c|c|c|c|c|c|}
\hline \multirow{2}{*}{ Catchment Name } & \multicolumn{2}{|c|}{ Streamflow (mm) } & \multicolumn{2}{|c|}{ Salinity (mg L ${ }^{-1}$ TDS) } & \multicolumn{2}{|c|}{ Salt Load $\left(\mathrm{kg} \mathrm{ha}^{-1}\right)$} \\
\hline & Observed & predicted & Observed & predicted & Observed & predicted \\
\hline Salmon & 119 & 135 & 142 & 142 & 175 & 175 \\
\hline Wights & 363 & 390 & 460 & 490 & 1665 & 1920 \\
\hline Ernies & 6.0 & 6.7 & 83 & 95 & 5.1 & 5.6 \\
\hline Lemon & 59 & 67 & 1160 & 1070 & 680 & 720 \\
\hline Maringee & 46 & 49 & 5875 & 5035 & 1875 & 2130 \\
\hline Batalling & 36 & 41 & 4680 & 4990 & 1480 & 1660 \\
\hline
\end{tabular}

\section{Parameter sensitivity \\ of a salt and water balance model}

M. A. Bari and

K. R. J. Smettem

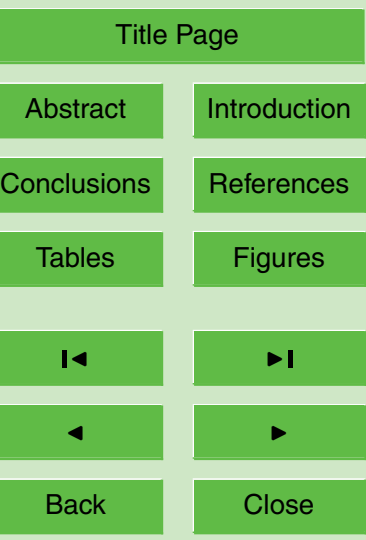

Full Screen / Esc

Print Version

Interactive Discussion 
2, 1405-1447, 2005

Table 3. Parameter values showing best fit results for all catchments.

\begin{tabular}{ccccccc}
\hline Parameter & Salmon & Wights & Ernies & Lemon & Maringee & Batalling \\
\hline$b$ & 0.256 & 0.56 & 0.256 & 0.456 & 0.256 & 0.256 \\
$c$ & 0.256 & 0.56 & 0.123 & 0.625 & 0.256 & 0.256 \\
$d$ & 2500 & 2500 & 2500 & 2500 & 2000 & 1900 \\
$i a$ & 3.15 & 2.15 & 2.65 & 2.15 & 2.55 & 2.50 \\
$K_{u v}$ & 17.185 & 27.185 & 15.29 & 27.185 & 27.185 & 27.185 \\
$K_{l \prime}$ & 530 & 450 & 530 & 1500 & 600 & 400 \\
$C_{u}$ & 0.0263 & 0.0163 & 0.0042 & 0.0063 & 0.0063 & 0.0063 \\
\hline
\end{tabular}

Parameter sensitivity

of a salt and water balance model

M. A. Bari and

K. R. J. Smettem

\section{Title Page}

Abstract

Introduction

Conclusions

References

Tables

Figures

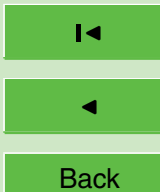

$\rightarrow$ I

Close

Full Screen / Esc

Print Version

Interactive Discussion

EGU 
2, 1405-1447, 2005

\section{Parameter sensitivity}

of a salt and water balance model

M. A. Bari and

K. R. J. Smettem

Table 4. (a) Goodness of fit for model simulations - streamflow.

\begin{tabular}{ccccccc}
\hline Measure of fit & Salmon & Wights & Ernies & Lemon & Maringee & Batalling \\
\hline$E I$ & 1.09 & 1.04 & 1.04 & 0.92 & 1.22 & 0.93 \\
$E^{2}$ & 0.76 & 0.91 & 0.84 & 0.83 & 0.96 & 0.85 \\
$C C$ & 0.93 & 0.96 & 0.92 & 0.93 & 0.98 & 0.94 \\
$E V$ & 0.76 & 0.92 & 0.84 & 0.84 & 0.96 & 0.86 \\
$E$ & 0.12 & 0.07 & 0.10 & 0.15 & 0.05 & 0.13
\end{tabular}

Title Page

Abstract

Conclusions

Tables

\section{4}

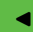

Back
Introduction

References

Figures

$\rightarrow 1$

Close

Full Screen / Esc

Print Version

Interactive Discussion 
2, 1405-1447, 2005

\section{Parameter sensitivity}

of a salt and water balance model

M. A. Bari and

K. R. J. Smettem

Table 4. (b) Goodness of fit for model simulations - salt.

\begin{tabular}{ccccccc}
\hline Measure of fit & Salmon & Wights & Ernies & Lemon & Maringee & Batalling \\
\hline$E^{2}$ & 0.77 & 0.83 & 0.91 & 0.85 & 0.53 & 0.66 \\
$C C$ & 0.90 & 0.92 & 0.96 & 0.93 & 0.85 & 0.85 \\
$E V$ & 0.77 & 0.85 & 0.91 & 0.86 & 0.54 & 0.67 \\
$E$ & 0.02 & 0.13 & 0.06 & -0.07 & 0.12 & 0.11 \\
\hline
\end{tabular}

Title Page

Abstract

Conclusions

Tables

\section{4}

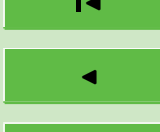

Back

Full Screen / Esc

Print Version

Interactive Discussion 
2, 1405-1447, 2005

Table 5. Relative sensitivities of selected parameters.

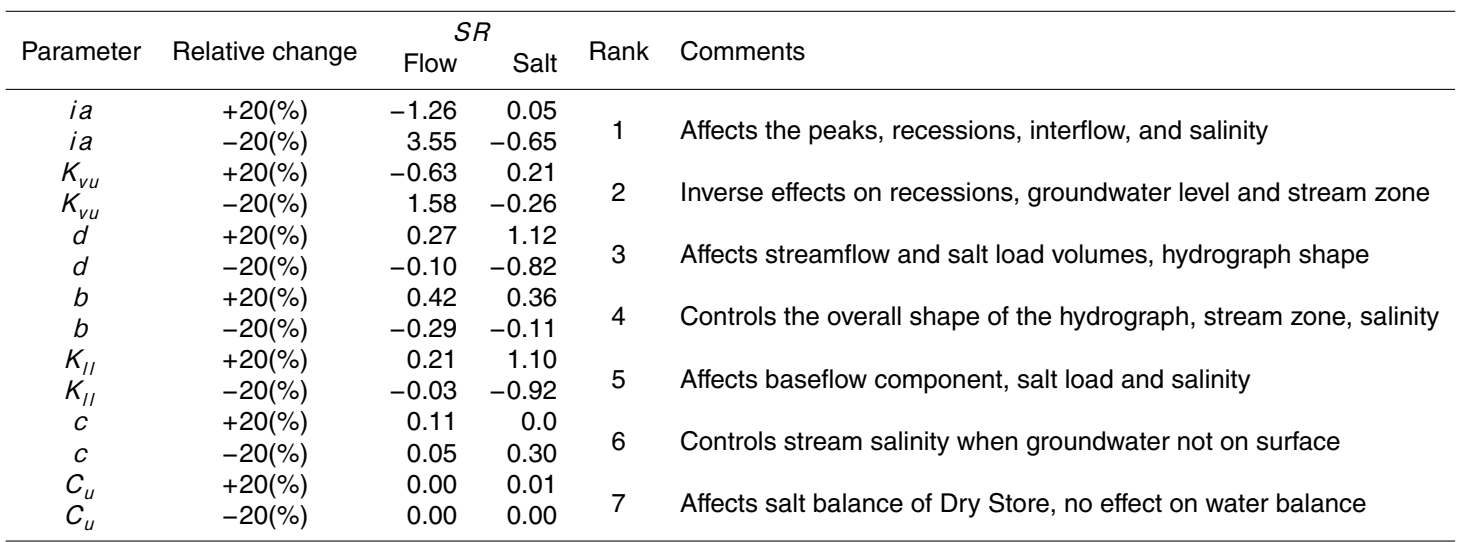

\section{Parameter sensitivity of a salt and water balance model}

M. A. Bari and

K. R. J. Smettem

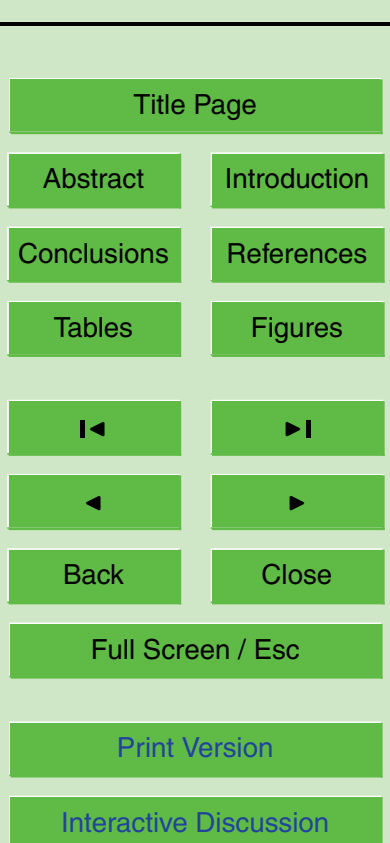

EGU 


\begin{tabular}{|c|c|c|c|}
\hline Parameters & Symbol & Unit & Value \\
\hline \multicolumn{4}{|l|}{ Known } \\
\hline Rooting depth, distribution & $R T$ & - & \\
\hline Catchment average slope & $\alpha$ & - & \\
\hline Stream length & $L$ & $\mathrm{~m}$ & \\
\hline Depth to groundwater level & $d_{g}$ & $\mathrm{~m}$ & \\
\hline Salt storage & $s^{9}$ & $\mathrm{~kg} \mathrm{~m}^{-3}$ & \\
\hline \multicolumn{4}{|l|}{ Fixed } \\
\hline Maximum Leaf Area Index & $L A I_{m x}$ & - & 3.00 \\
\hline Leaf Area Index & $\mathrm{LAI}^{m x}$ & - & $0-2.1$ \\
\hline Interception store coefficient & $C_{i}$ & - & 0.70 \\
\hline Through fall constant & $a_{1}$ & - & 0.5 \\
\hline Soil evaporation constant & $c s$ & - & 1.4 \\
\hline Transpiration exponent & $t u$ & - & 1.35 \\
\hline Threshold moisture content of Dry Store & $\theta_{d m n}$ & - & 0.08 \\
\hline Maximum moisture content of any elementary area of Dry Store & $\theta_{d m x}$ & - & 0.35 \\
\hline Maximum moisture content of any elementary area of Wet Store & $\theta_{f m x}^{d m x}$ & - & 0.6 \\
\hline Soil depth distribution of Subsurface Store & $a^{1}$ & - & 1.32 \\
\hline Maximum moisture content of any elementary area of Subsurface Store & $\theta_{\operatorname{lmx}}$ & - & 0.55 \\
\hline Lateral hydraulic conductivity of top soil & $K_{u l}$ & $m m$ day $^{-1}$ & 395.0 \\
\hline Wet Store moisture content threshold for interflow & $\theta_{w m n}$ & $\mathrm{~mm}$ & 0.006 \\
\hline Percolation coefficient for seasonal variability & $p b$ & - & 0.5 \\
\hline Relationship between vertical conductivity and moisturecontent of Subsurface Store & pa & - & 1.5 \\
\hline Vertical hydraulic conductivity of Subsurface Store & $K_{/ v}$ & mm day ${ }^{-1}$ & 0.3539 \\
\hline Loss of groundwater below gauge & $C_{\text {loss }}$ & day $^{-1}$ & 0.000000125 \\
\hline Salt release from Dry to Wet Store & $C_{u}$ & - & 0.05 \\
\hline \multicolumn{4}{|l|}{ Variable } \\
\hline Relationship between lateral conductivity and moisture content of top soil & ia & - & 1.9 \\
\hline Vertical conductivity of top soil & $K_{u v}$ & mm day ${ }^{-1}$ & 27.185 \\
\hline Moisture retention capacity distribution - Dry Store & $b$ & - & 0.256 \\
\hline Moisture retention capacity distribution - Wet Store & $c$ & - & 0.256 \\
\hline Top soil depth & $d$ & $\mathrm{~m}$ & 2.0 \\
\hline Salt release from Dry to Wet Store & $C_{u}$ & - & 0.01330 \\
\hline Saturated lateral hydraulic conductivity of Groundwater Store & $K_{/ I}$ & $\mathrm{~mm}_{\text {day }}{ }^{-1}$ & 400.00 \\
\hline
\end{tabular}

\section{Parameter sensitivity of a salt and water balance model}
M. A. Bari and

K. R. J. Smettem

Maximum Leaf Area Index

Leaf Area Index

Interception store coefficient

$\angle A I$

$C_{i}$

$a_{1}$

tu

$\theta_{d m n}$

$\theta_{d m x}$

$\theta_{f m x}$

$\theta_{\operatorname{lmx}}$

$K_{u l}$

$\theta_{w m n}$

$p b$

pa

$K_{/ v}$

$C_{\text {loss }}$

$K_{u v}$

$b$

$C_{u}$

$K_{\text {II }}$
Title Page

\section{Abstract}

Conclusions

Tables

References

Figures
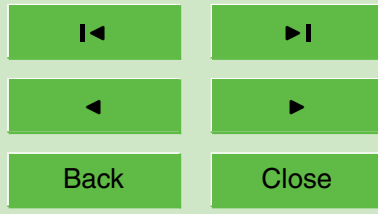

Full Screen / Esc

Print Version

Interactive Discussion 


\section{HESSD}

2, 1405-1447, 2005

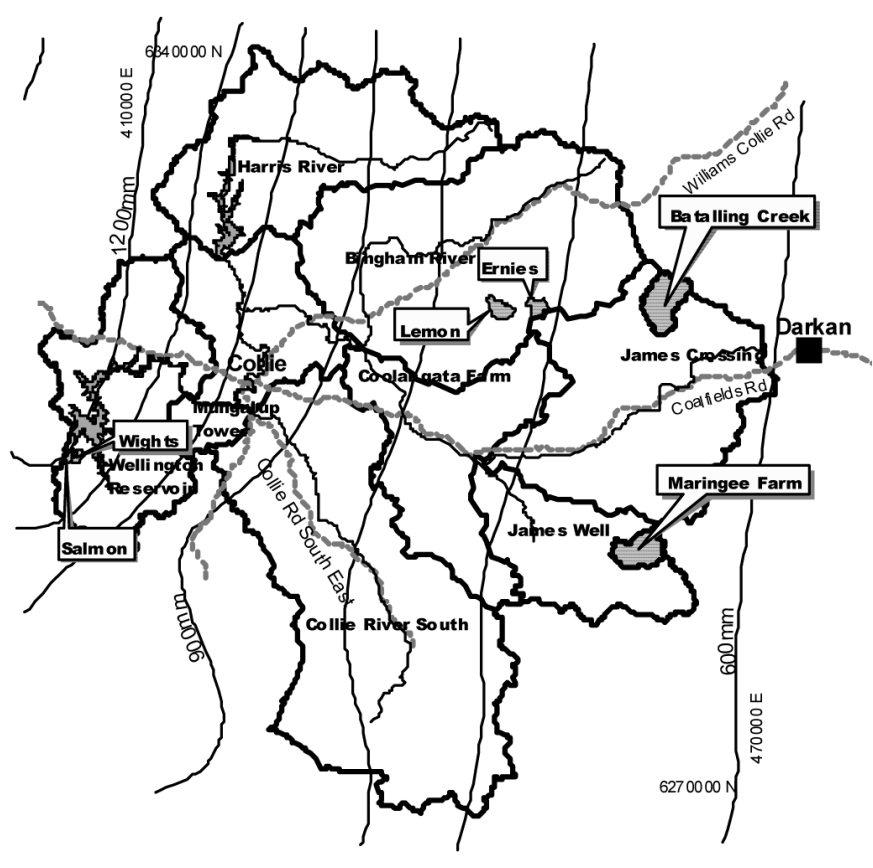

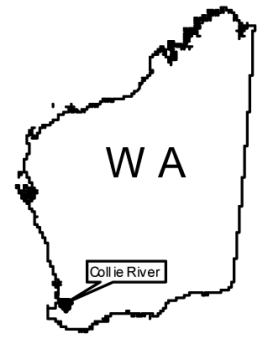

\section{Legend}

$\square$ Experimental catchment "Main roads

N Subcatchment

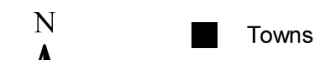

$\wedge$ Rivers

$\square$ Reservoir

_ Rainfall isohyet $(\mathrm{mm})$

10 Kilometres
Parameter sensitivity of a salt and water balance model

M. A. Bari and

K. R. J. Smettem

Title Page

Abstract

Introduction

Conclusions

References

Tables

Figures

14

I

4

Back

Fig. 1. Location of experimental catchments.

Full Screen / Esc

Print Version

Interactive Discussion 


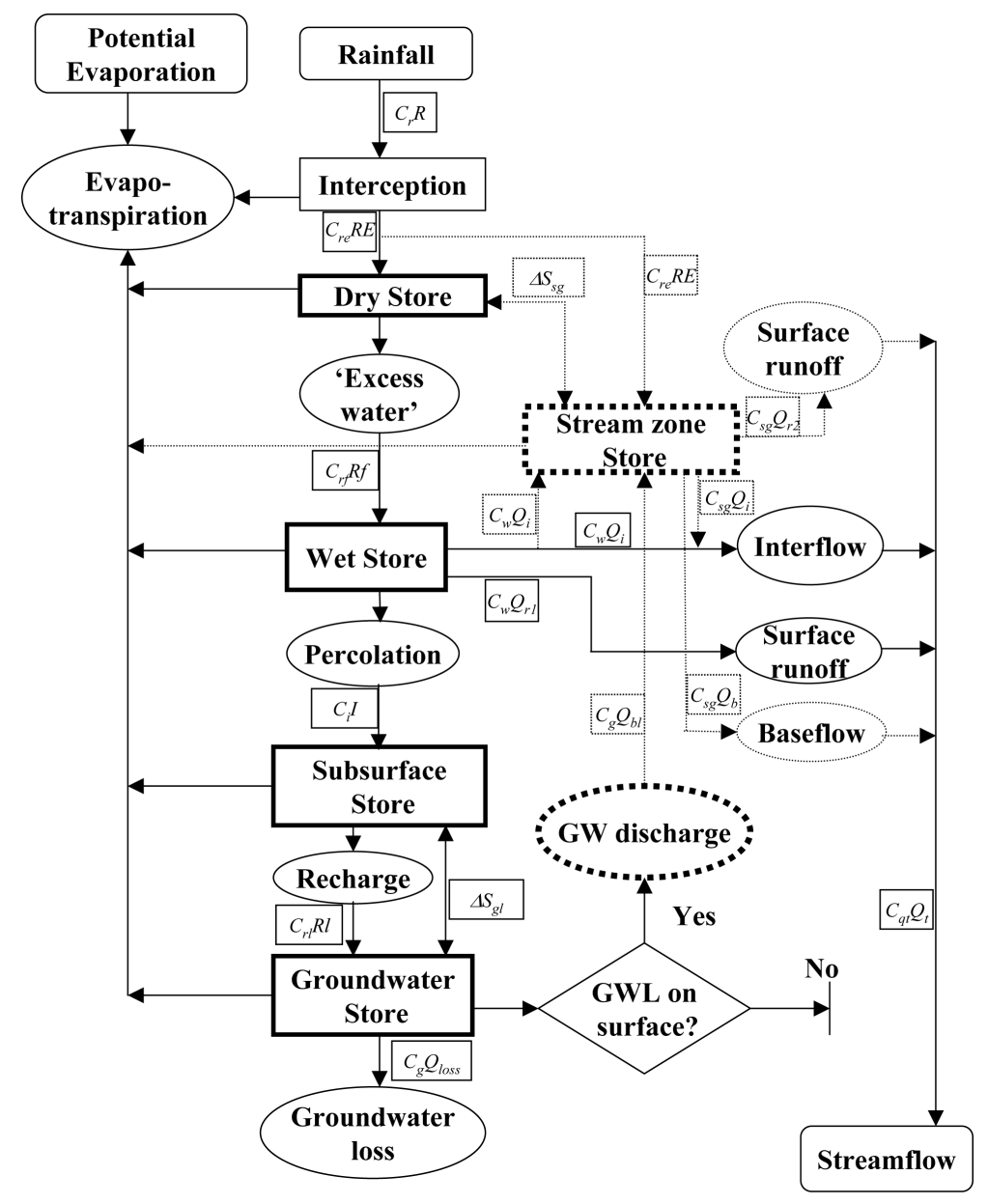

HESSD

2, 1405-1447, 2005

\section{Parameter sensitivity \\ of a salt and water balance model}

M. A. Bari and

K. R. J. Smettem

\section{Title Page}

\section{Abstract}

Conclusions

\section{Tables}

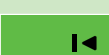

14

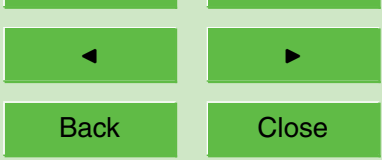

Full Screen / Esc

Print Version

Interactive Discussion

Fig. 2. Flow chart of the hydrological sub-processes in the water and salt balance model (after Bari and Smettem, 2005b). 


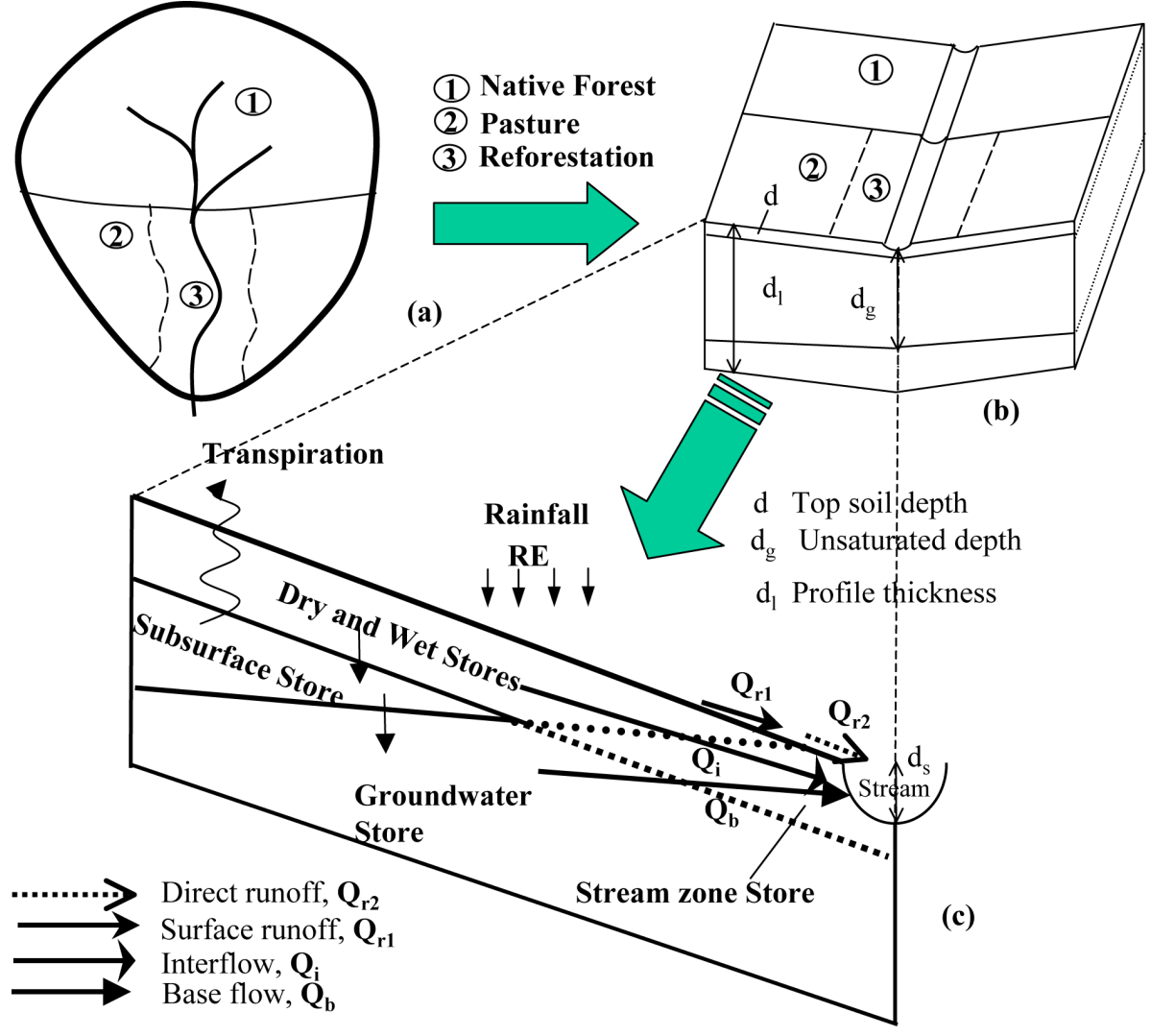

Fig. 3. Conceptual representation of (a) native forest, pasture and reforestation, (b) two landuse fractions and (c) water balance components.

\section{HESSD}

2, 1405-1447, 2005

\section{Parameter sensitivity of a salt and water balance model}

M. A. Bari and

K. R. J. Smettem

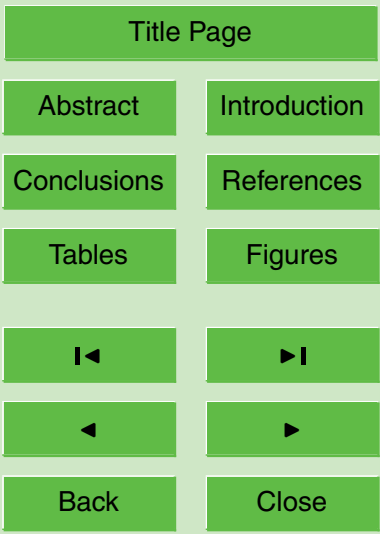

Full Screen / Esc

Print Version

Interactive Discussion 

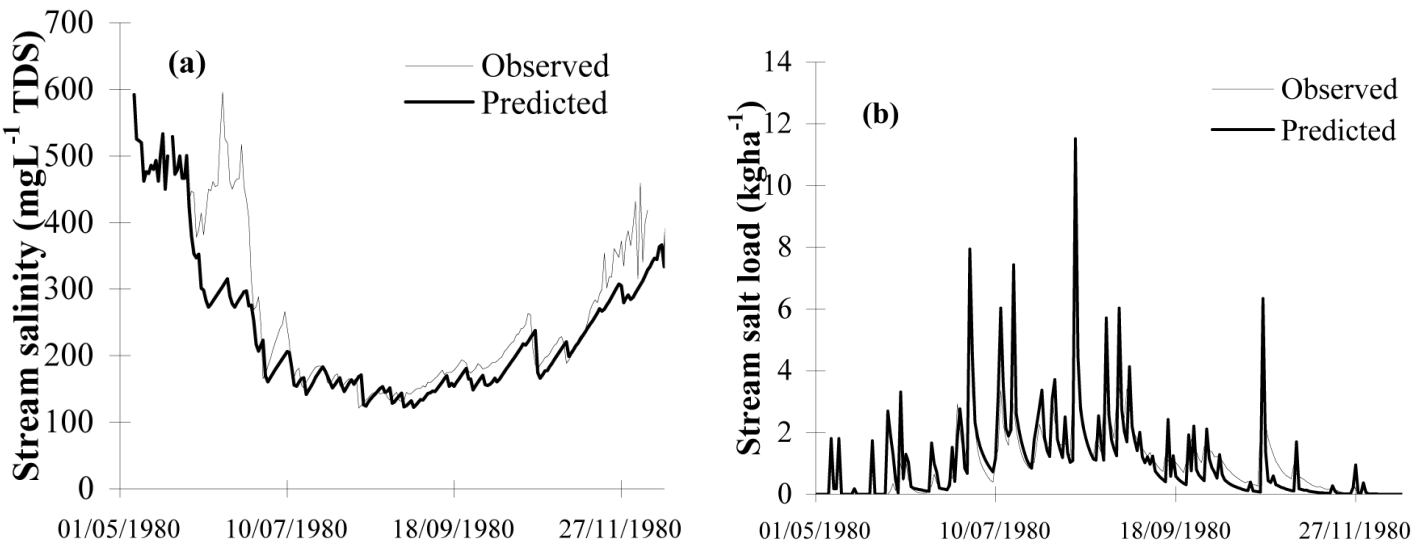

\section{Parameter sensitivity of a salt and water balance model}

M. A. Bari and

K. R. J. Smettem

$01 / 05 / 1980 \quad 10 / 07 / 1980 \quad 18 / 09 / 1980 \quad 27 / 11 / 1980$

$01 / 05 / 1980$

$10 / 07 / 1980$

$27 / 11 / 1980$

Fig. 4. Observed and predicted (a) stream salinity and (b) salt load graph of Salmon catchment.

Title Page

\section{Abstract}

Conclusions

Tables

References

Figures

14

Back

Close 

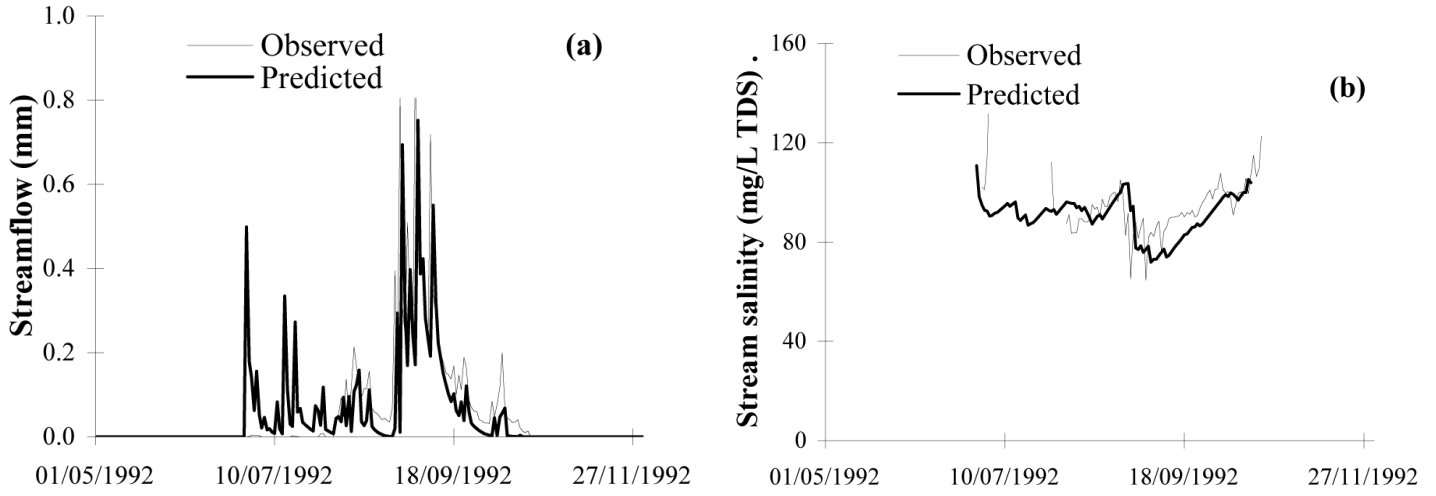

\section{Parameter sensitivity of a salt and water balance model}

M. A. Bari and

K. R. J. Smettem

Fig. 5. Observed and predicted (a) streamflow and (b) salinity of Ernies catchment. 
2, 1405-1447, 2005

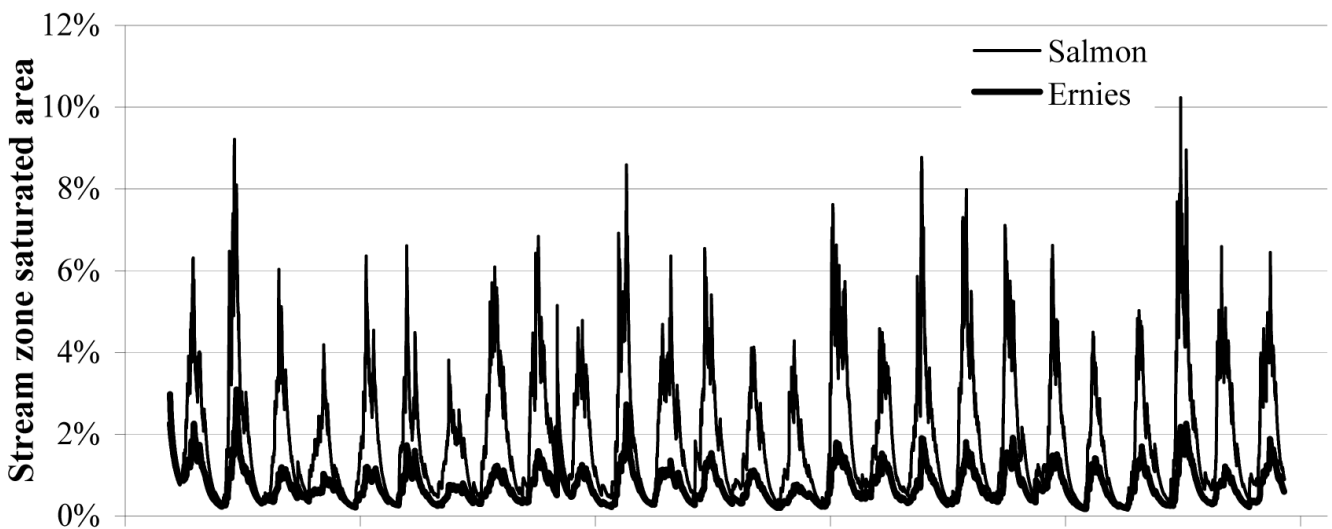
$01 / 01 / 1972$
23/06/1977
$14 / 12 / 1982$
$05 / 06 / 1988$
26/11/1993
$19 / 05 / 1999$

Fig. 6. Dynamic variation of stream zone saturated areas at Ernies and Salmon catchments.

\section{Parameter sensitivity of a salt and water balance model}

M. A. Bari and

K. R. J. Smettem

\section{Title Page}

Abstract

Introduction

Conclusions

References

Tables

Figures

14

-I

4

Back

Close

Print Version 

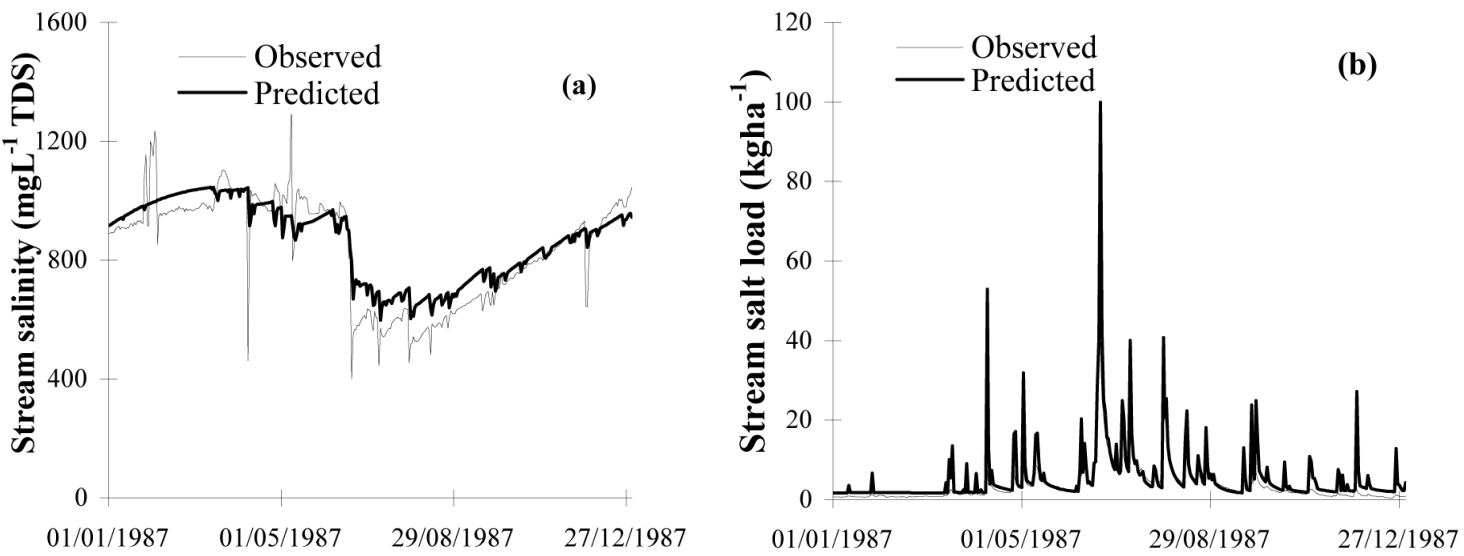

\section{Parameter sensitivity of a salt and water balance model}

M. A. Bari and

K. R. J. Smettem

Fig. 7. Observed and predicted (a) streamflow, (b) salinity, and (c) salt load graph of Wights catchment. 


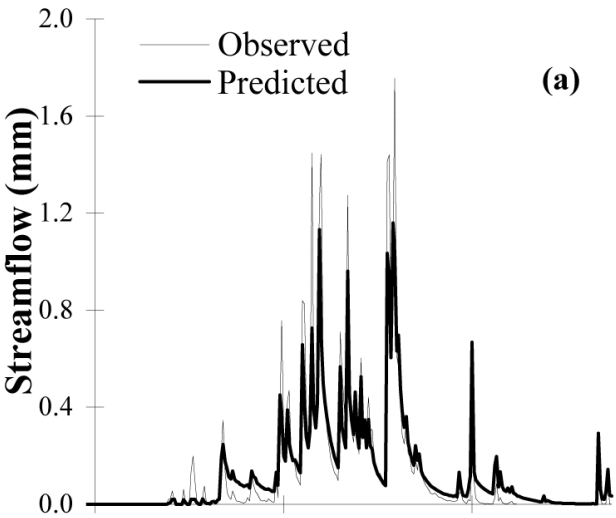

01/04/1995

$10 / 07 / 1995$

$18 / 10 / 1995$

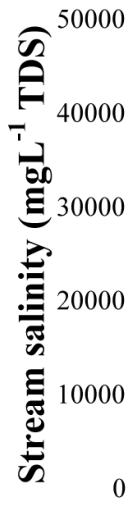

$01 / 04 / 1995$

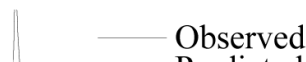

Observed

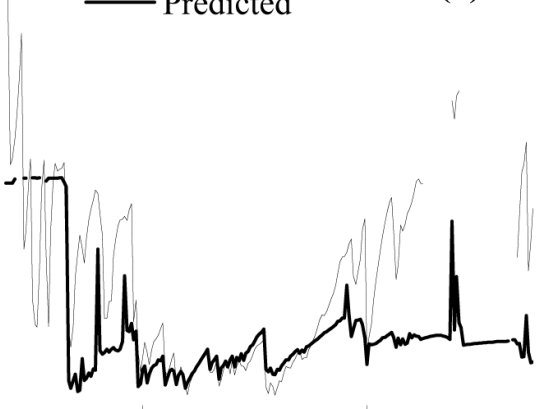

$10 / 07 / 1995$

$18 / 10 / 1995$

Fig. 8. Observed and predicted (a) streamflow and (b) salinity of Maringee Farm catchment.

\section{Parameter sensitivity of a salt and water balance model}

M. A. Bari and

K. R. J. Smettem

\section{Title Page}

\section{Abstract}

Introduction

Conclusions

References

Tables

Figures

14

- I

4

Back

Close

Print Version 

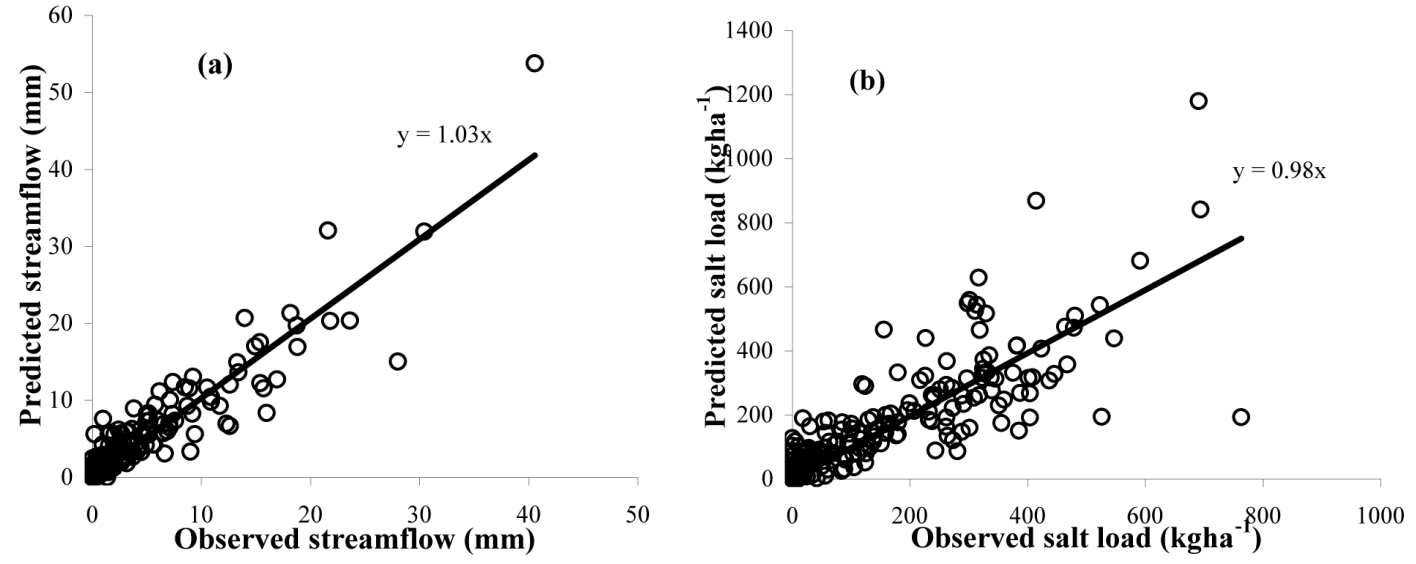

Fig. 9. Observed and predicted monthly (a) streamflow and (b) salt load of Batalling Creek catchment.

\section{Parameter sensitivity of a salt and water balance model}

M. A. Bari and

K. R. J. Smettem

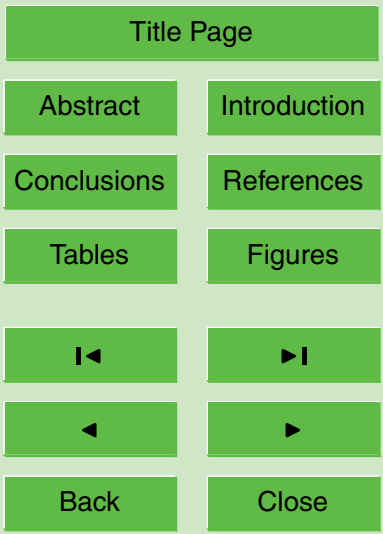

Full Screen / Esc

Print Version

Interactive Discussion 


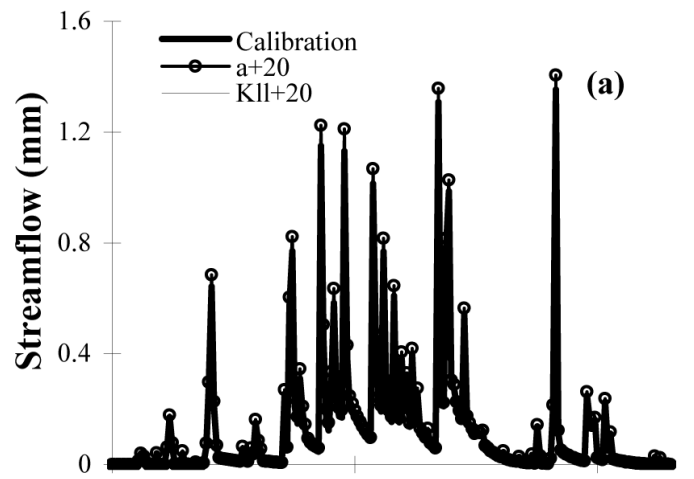

01/05/1995
$02 / 08 / 1995$

03/11/1995

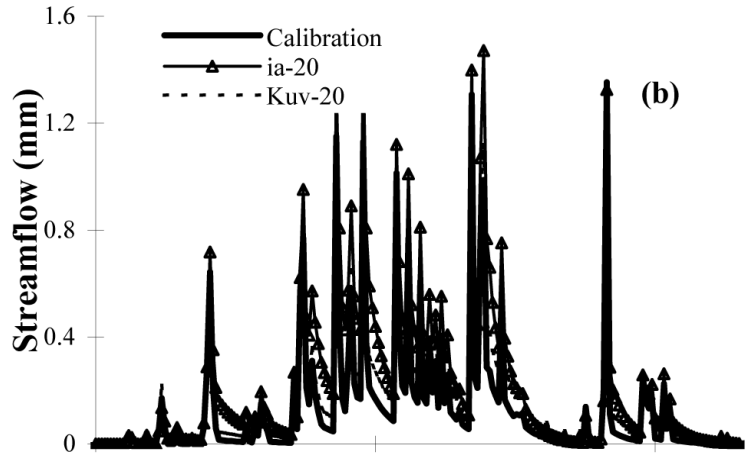

\section{Parameter sensitivity of a salt and water balance model}

M. A. Bari and

K. R. J. Smettem

\section{Title Page}

02/08/1995

Abstract

Conclusions

Tables

01/05/1995
$03 / 11 / 199$

\section{4}

Fig. 10. Sensitivity analyses of daily streamflow. 

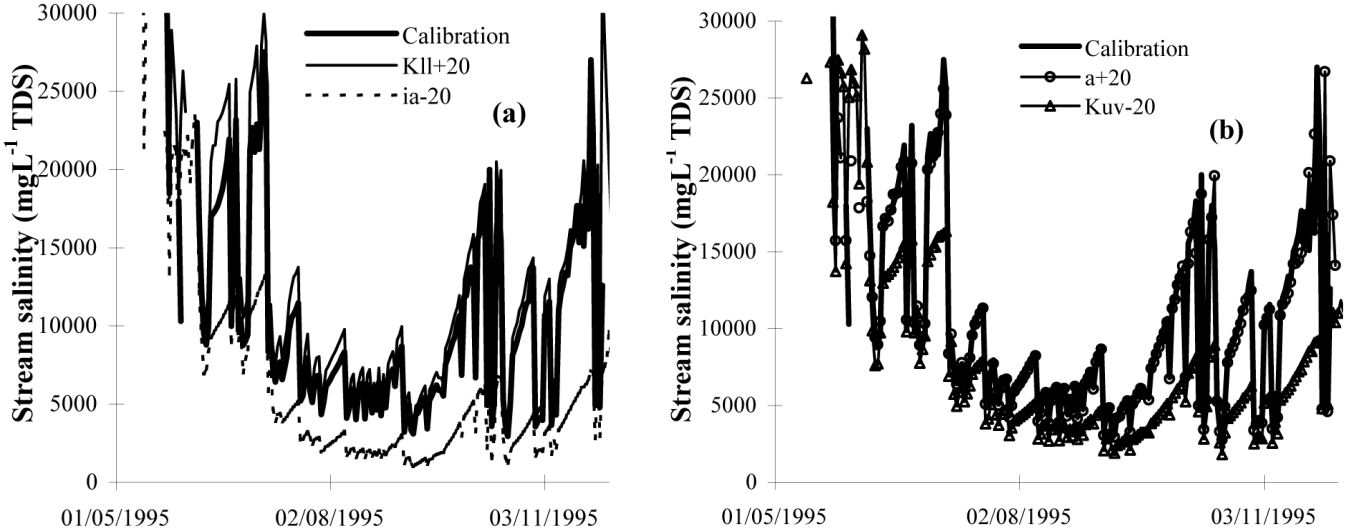

01/05/1995

02/08/1995

03/11/1995
Parameter sensitivity of a salt and water balance model

M. A. Bari and K. R. J. Smettem

Title Page

Abstract

Introduction

Conclusions

References

Tables

Figures

14

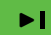

4

Back

Close

Full Screen / Esc

Print Version

Interactive Discussion 

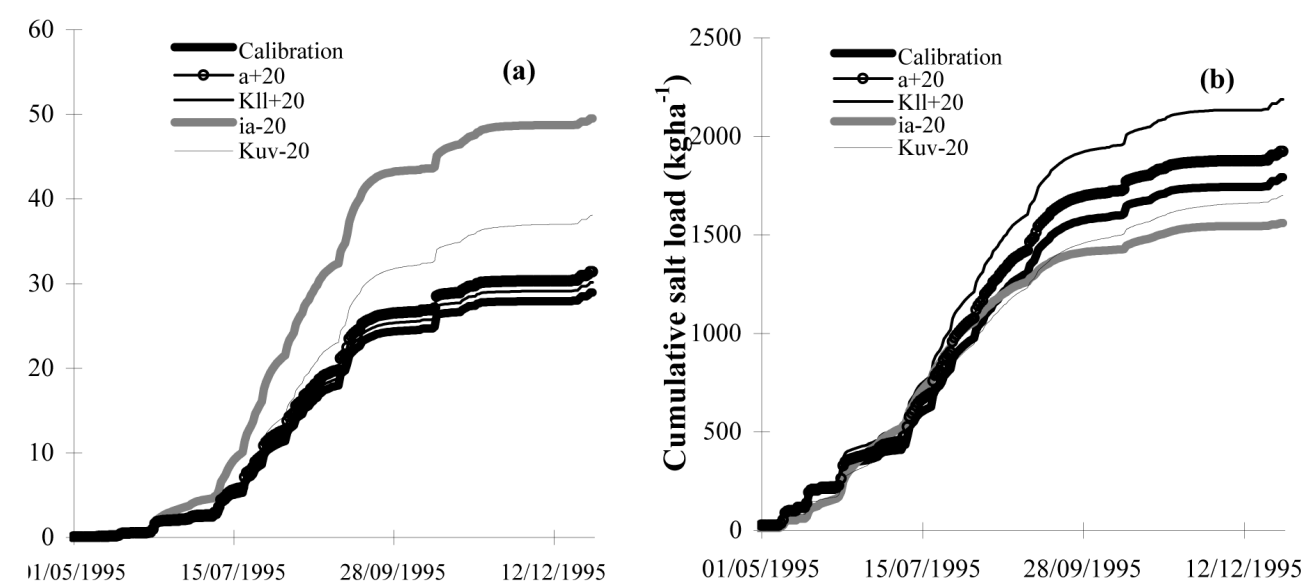

Fig. 12. Cumulative distribution of daily (a) streamflow and (b) salt load due to sensitivity analyses.

\section{Parameter sensitivity of a salt and water balance model \\ M. A. Bari and \\ K. R. J. Smettem

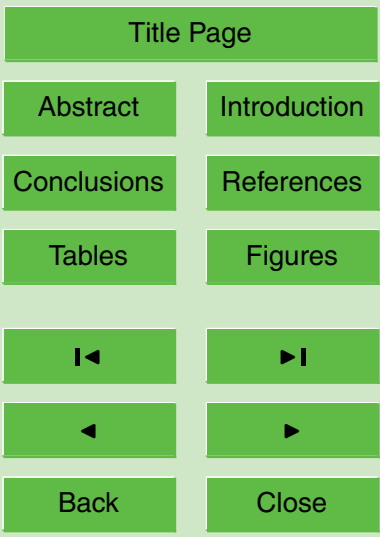

Full Screen / Esc

Print Version

Interactive Discussion 